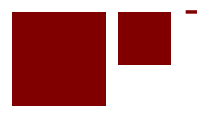

C E N T E R for

RETIREMENT

RE S E A R C H

at BOSTON COLLEGE

\title{
FAILURE TO CONTRIBUTE: AN ESTIMATE OF THE CONSEQUENCES OF NON- AND UNDERPAYMENT OF SELF-EMPLOYMENT TAXES BY INDEPENDENT CONTRACTORS AND ON-DEMAND WORKERS ON SOCIAL SECURITY
}

\author{
Caroline Bruckner and Thomas L. Hungerford
}

CRR WP 2019-1

January 2019
Center for Retirement Research at Boston College
Hovey House
140 Commonwealth Avenue
Chestnut Hill, MA 02467

Tel: 617-552-1762 Fax: 617-552-0191

http://crr.bc.edu

Caroline Bruckner is on the faculty of American University's Kogod School of Business and is the managing director of the Kogod Tax Policy Center. Thomas L. Hungerford is an independent economic consultant. The research reported herein was performed pursuant to a grant from the U.S. Social Security Administration (SSA) funded as part of the Retirement Research Consortium. The opinions and conclusions expressed are solely those of the authors and do not represent the opinions or policy of SSA, any agency of the federal government, American University, or Boston College. Neither the United States Government nor any agency thereof, nor any of their employees, makes any warranty, express or implied, or assumes any legal liability or responsibility for the accuracy, completeness, or usefulness of the contents of this report. Reference herein to any specific commercial product, process or service by trade name, trademark, manufacturer, or otherwise does not necessarily constitute or imply endorsement, recommendation or favoring by the United States Government or any agency thereof.

(C) 2019, Caroline Bruckner and Thomas L. Hungerford. All rights reserved. Short sections of text, not to exceed two paragraphs, may be quoted without explicit permission provided that full credit, including (C) notice, is given to the source. 


\begin{abstract}
About the Steven H. Sandell Grant Program
This paper received funding from the Steven H. Sandell Grant Program for Junior Scholars in Retirement Research. Established in 1999, the Sandell program's purpose is to promote research on retirement issues by scholars in a wide variety of disciplines, including actuarial science, demography, economics, finance, gerontology, political science, psychology, public administration, public policy, sociology, social work, and statistics. The program is funded through a grant from the Social Security Administration (SSA). For more information on the Sandell program, please visit our website at: http://crr.bc.edu/?p=9570, send e-mail to crr@bc.edu, or call (617) 552-1762.
\end{abstract}

\title{
About the Center for Retirement Research
}

The Center for Retirement Research at Boston College, part of a consortium that includes parallel centers at the University of Michigan and the National Bureau of Economic Research, was established in 1998 through a grant from the Social Security Administration. The Center's mission is to produce first-class research and forge a strong link between the academic community and decision-makers in the public and private sectors around an issue of critical importance to the nation's future. To achieve this mission, the Center sponsors a wide variety of research projects, transmits new findings to a broad audience, trains new scholars, and broadens access to valuable data sources.

Center for Retirement Research at Boston College

Hovey House

140 Commonwealth Ave

Chestnut Hill, MA 02467

Tel: 617-552-1762 Fax: 617-552-0191

http://crr.bc.edu

Affiliated Institutions:

The Brookings Institution

Mathematica - Center for Studying Disability Policy

Syracuse University

Urban Institute 


\section{Abstract}

While existing academic and government research has focused on the size, growth trajectory, and labor and tax law implications of independent contractors, freelancers, and workers selling goods and services online and through app-based platforms (the "on-demand" economy), less work has been devoted to quantifying the Social Security implications for the ondemand economy and its workers. Although it is known that self-employed workers have tax compliance and reporting issues, the existing reporting rules applicable to most workers earning income in the on-demand economy substantially increase the likelihood that these taxpayers are failing to contribute to Social Security and Medicare through payment of the self-employment tax (SE tax). As such, this paper sheds light on the Social Security implications of current federal tax rules for independent contractors generally and, in particular, workers earning income through occupations occurring in the on-demand economy by estimating the population and earnings of these workers using the U.S. Census Bureau's redesigned Survey of Income and Program Participation (SIPP).

By analyzing 2014 SIPP data, we identify a population of self-employed, non-employer respondents working outside of a traditional employment relationship ("independent contractors"), as well as individuals working in occupations in the on-demand economy ("ondemand workers"). SIPP data have the potential to capture workers who earn income using ondemand platforms to connect with customers and process payments ("on-platform work"), as well as workers who earn income in occupations occurring in the on-demand economy who do not use on-demand platforms ("off-platform work").

Additionally, with SIPP data, we are able to estimate the income that independent contractors and on-demand workers earned in these employment relationships in 2014. Using Internal Revenue Service (IRS) data on the tax gap, U.S. Treasury Department audit data on underpayment of the SE tax, and survey data on tax compliance by on-demand economy workers and the self-employed, we are able to create an estimate of how much SE tax should have been paid on this income but likely was not. To provide context for our findings, we applied the methodology we developed to estimate the likely underpayment of the SE tax to data published in 2018 by the U.S. Bureau of Labor Statistics on the number of independent contractors and onplatform workers in 2017. In addition, using SIPP, we were able to provide supplemental demographic data on independent contractors and the on-demand platform workforce. 
The paper found that:

- Approximately 7.1 million individuals were independent contractors, and 3.1 million individuals were on-demand workers in 2014.

- Using SIPP data, we estimated that independent contractors earned approximately $\$ 204.1$ billion in income in 2014, and on-demand workers earned approximately $\$ 36.0$ billion in 2014.

- Based on our review of SIPP data and existing measures of misreported self-employment income, we estimate at least 3.1 million independent contractors underreported selfemployment income in 2014. This underreporting would result in approximately $\$ 4.8$ billion in SE tax that should have been paid, with approximately $\$ 3.9$ billion constituting non-payment of Social Security contributions.

- Using SIPP, as well as existing research on tax compliance and information reporting for on-demand workers and the self-employed, we estimate that $\$ 2.5$ billion in SE tax was not reported or underreported by on-demand workers in 2014. This translates to $\$ 2.0$ billion that was not paid into Social Security.

- Using SIPP, we found that independent contractors were most often Baby Boomers (i.e., ages 55 and over), were more likely to be women than men, and were more often white than any other race or ethnicity. On-demand workers were more often Generation X (i.e., ages 34-54), more likely to be women than men, and were most frequently white, rather than any other race or ethnicity.

- Our estimates of the likely additional SE tax owed by independent contractors generally, and more specifically by workers in the on-demand economy, could undermine efforts to fund Social Security and translate to lower Social Security benefits for these workers upon retirement.

The policy implications of the finding are:

- Policymakers could consider proposals targeted to increase tax compliance and Social Security contributions for independent contractors generally, and for the on-demand economy workforce in particular. 
- Congress could take steps to modernize information reporting, update quarterly estimated payment requirements, and require distribution of tax guidance to help combat underreporting of self-employment income and support the solvency of Social Security. 


\section{Introduction}

In the past 10 years, companies like Uber, Etsy, Lyft, Airbnb, and Rover.com have become household names by connecting consumers and service providers and sellers online and through app-based programs that users download to their smartphones (the "on-demand economy" or "gig economy"). ${ }^{1}$ As of September 2018, at least 2.3 million Americans earned income every month by renting rooms, giving rides, running errands and selling goods using an app-based platform. ${ }^{2}$ In fact, the latest research finds that at least 5.5 million households earn income from the on-demand economy every year. ${ }^{3}$ And this work is projected to continue to grow, along with the convenience of accessing goods and services through apps on smartphones. ${ }^{4}$ In fact, the tax preparer industry is banking on it.

For example, in 2017 the CEO of Intuit, the parent company of TurboTax, estimated that 34 percent of the U.S. workforce participated in the gig economy, with an expected growth to 43 percent by $2020 .^{5}$ Although self-employed workers have been a longstanding feature of the U.S.

\footnotetext{
${ }^{1}$ Caroline Bruckner, "Shortchanged: The Tax Compliance Challenges of Small Business Operators Driving the OnDemand Platform Economy," Kogod Tax Policy Center, (2016)

https://www.american.edu/kogod/news/Shortchanged.cfm

${ }^{2}$ Diana Farrell, Fiona Greig, \& Amar Hamoudi. 2018. "The Online Platform Economy in 2018: Drivers, Workers, Sellers and Lessors." JPMorgan Chase Institute (Sept. 2018), https://www.jpmorganchase.com/corporate/institute/document/institute-ope-2018.pdf (the "JPMCI 2018 Study"). The authors updated findings from prior work in September 2018 to reflect data from a sample of 39 million Chase checking accounts that tracked payments from 128 online platforms to 2.3 million families from Oct. 2012-March 2018. In the updated study, the online platforms, which connect customers to sellers or service providers and mediate payment, were grouped into four categories: transportation (e.g., driving goods or people); non-transport (e.g., dog walking, home care, home repair, telemedicine); selling through an online marketplace; and leasing (e.g., renting homes, parking spaces and other assets). See also, Diana Farrell \& Fiona Greig, "Paychecks, Paydays, and the On-demand Platform Economy: Big Data on Income Volatility," J.P. Morgan Chase Institute, 1-43 (Feb. 2016), https://www.jpmorganchase.com/corporate/institute/report-paychecks-paydays-and-the-online-platformeconomy.htm (the "JPMCI 2016 Study").

${ }^{3}$ JPMCI 2018 Study at 23.

${ }^{4} I d$. In fact, MBO Partners, a tax and accounting firm focused on the independent workforce that has produced an annual study of the size of the independent workforce since 2010, estimated that the independent workers rose to number almost 42 million - up 2.2 percent-from 2017. MBO Partners, "The State of Independence in America 2018: The New Normal," (2018), https://www.mbopartners.com/uploads/files/state-of-independencereports/State_of_Independence_2018.pdf (last visited Sept. 9, 2018) (the "MBO 2018 Report"); Microeconomix, "The App Economy In the United States: A Review of the Mobile App Market and Its Contribution to the United States Economy," Deloitte (Aug. 20, 2018), https://www.ftc.gov/system/files/documents/public_comments/2018/08/ftc-2018-0048-d-0121-155299.pdf (last visited Sept. 8, 2018) (finding that the app economy in 2018 represented $\$ 339.6$ billion in direct economic impact). ${ }^{5}$ Patrick Gillespie, "Intuit: Gig economy is 34 percent of US workforce," CNN Money, (May 24, 2017), https://money.cnn.com/2017/05/24/news/economy/gig-economy-intuit/index.html Additionally, the Freelancers Union and Upwork found that 57.3 million Americans were working as independent contractors in 2017, which was approximately 36 percent of the U.S. workforce. "Freelancing in America: 2017." Upwork \& Freelancers Union, Oct. 17, 2017), www.upwork.com/i/freelancing-in-america/2017 (the "FIA 2017 Report").
} 
workforce, "side hustles" facilitated platforms that connect customers with sellers and service providers and process payment electronically ("on-demand platforms") are becoming an increasingly common strategy for workers to earn income outside of traditional work arrangements, with the income "being a luxury for some and a necessity for others." 6 Moreover, some industry research suggests workers are looking to the on-demand economy as a means of supplementing their retirement savings and to "age in place."7

Along with the notable rise of on-demand platforms, academic research and Congressional inquiry have begun to consider the tax compliance challenges and federal tax policy implications of service providers and sellers earning income in the on-demand economy. ${ }^{8}$ For example, Congressional testimony in July 2018 informed members of the U.S. Senate Committee on Finance that the current tax rules for reporting income for on-demand economy earnings virtually ensure that more taxpayers are more likely to misreport their income and face audit and penalty exposure. ${ }^{9}$ In fact, IRS taxpayer data released in 2017 confirm these

\footnotetext{
${ }^{6}$ Aaron Smith, "Gig Work, Online Selling and Home Sharing." Pew Research Center: Internet, Science \& Tech, (Nov. 17, 2016), www.pewinternet.org/2016/11/17/gig-work-online-selling-and-home-sharing ${ }^{7}$ Airbnb's Growing Community of 60+ Women Hosts, Airbnb (Mar. 2016), https://www.airbnbaction.com/wpcontent/uploads/2016/03/Airbnb_60_Plus_Women_Report.pdf; Airbnb's Growing Economic Opportunities for D.C. Seniors Home - Sharing: Bringing \$5.5 Million to D.C. Residents Age 60+ and Helping Them Age in Place, Airbnb (March 2018), https://2sqy5r1jf93u30kwzc1smfqt-wpengine.netdna-ssl.com/wp-

content/uploads/2018/03/REPORT_-Senior-Airbnb-Hosts-in-D.C.-March-2018-1.pdf (noting the typical D.C. senior host made $\$ 10,600$ renting their home to D.C. visitors).

${ }^{8}$ See e.g., Bruckner, supra n. 1; Shu-Yi Oei \& Diane Ring, Can Sharing Be Taxed?, 93 Wash. Univ. L. Rev. 4 (2016); Kathleen Delaney Thomas, Taxing the Gig Economy, 166 University of Pennsylvania L. Rev. 1415 (2018); Shu-Yi Oei \& Diane M. Ring, The Tax Lives of Uber Drivers: Evidence from Internet Discussion Forums. (Feb. 10, 2016), http://papers.ssrn.com/sol3/papers.cfm?abstract_id=2730893. See also, Targeted Tax Reform: Solutions to Relieve the Tax Compliance Burden(s) For America's Small Businesses: Hearing Before the U.S. Senate Comm. on Small Business and Entrepreneurship (testimony of Caroline Bruckner) $114^{\text {th }}$ Congress (July 2015), https://www.sbc.senate.gov/public/_cache/files/d/c/dc25e509-6b65-4888-9ce2dce63a215c5e/54054E85263006E642152871A2E8E14E.bruckner-testimony.pdf; The Sharing Economy: A Taxing Experience for New Entrepreneurs Part I: Hearing Before the U.S. House Comm. on Small Business, $114^{\text {th }}$ Congress (testimony of Caroline Bruckner) (May 2016), https://smallbusiness.house.gov/uploadedfiles/5-2416_bruckner_testimony_.pdf ("House May 2016 Testimony"); Small Business Tax Reform: Modernizing the Code for the Nation's Job Creators: Hearing Before the U.S. House Comm. on Small Business, $115^{\text {th }}$ Congress (testimony of Caroline Bruckner) (Oct. 2017), https://smallbusiness.house.gov/uploadedfiles/10-4-17_bruckner_testimony.pdf ("House Oct. 2017 Testimony"); Caroline Bruckner, "Congress Failed to Fix Tax Woes for Gig Workers," Chicago Tribune (Feb. 16, 2018), http://www.chicagotribune.com/news/opinion/commentary/ct-perspec-gig-economy-taxesuber-lyft-airbnb-0216-20180215-story.html (last visited Sep 9, 2018); Letter from Kogod Tax Center to Business Working Group of U.S. Senate Committee on Finance (April 15, 2015), https://www.finance.senate.gov/legislation/details/business-tax-working-group-submissions ${ }^{9}$ Improving Tax Administration Today: Hearing Before the U.S. Senate Committee on Finance Subcommittee on Taxation and IRS Oversight, $115^{\text {th }}$ Congress (2018) (testimony of Caroline Bruckner) available at https://www.finance.senate.gov/imo/media/doc/26JUL2018BrucknerSTMNT.pdf (“Senate July 2018 Testimony”).
} 
consequences to a certain degree. According to a 2017 analysis prepared by The Wall Street Journal, "the number of filers penalized for underpaying estimated taxes rose nearly 40 percent between 20102015 - to 10 million." 10

Not only do the tax compliance challenges of these taxpayers result in widespread underreporting, penalties and audit exposure for income taxes, but these challenges also implicate the Social Security and Medicare taxes due on self-employment income ("SE tax"). Failure to properly report income and pay the SE tax undermine Social Security solvency and can reduce workers' future retired-worker benefits that are calculated by formula based on a workers Average Indexed Monthly Earnings." 11 Keep in mind, Social Security is a "selffinancing program" funded primarily through payroll taxes paid by covered workers and employers in addition to SE taxes paid by self-employed individuals. ${ }^{12}$

And while existing private sector and academic research has reviewed the size, growth trajectory and labor law implications of the on-demand economy, as well as the income tax, compliance and benefits issues triggered by its workers, less work has been devoted to quantifying the SE tax and Social Security implications of the significant number of taxpayers who either underreport or fail to remit Social Security contributions. ${ }^{13}$ This matters because "the most fundamental shortcoming of the current [U.S. retirement] system is that millions of working Americans have no easy way to save for retirement on the job outside of Social Security." 14 But what if most Americans working in the on-demand economy aren't even contributing to Social Security?

\footnotetext{
${ }^{10}$ Laura Saunders, "Number of Americans Caught Underpaying Their Taxes Surges 40 percent." Wall Street Journal, (Aug. 11, 2017) available at https://www.wsj.com/articles/the-numberof-americans-caughtunderpayingsometaxes-surges-40-1502443801

${ }^{11}$ Barry F. Huston, Cong. Research Serv. No. R42035, Social Security Primer, (July 13, 2018), https:/fas.org/sgp/crs/misc/R42035.pdf (CRS Report R42035). See also Part V.B. infra.

12 See CRS Report R42035.

${ }^{13}$ However, there has been some important work on on-demand workers income insecurity, Social Security and retirement issues. See Janine Berg, Income Security in the On-Demand Economy: Findings and Policy Lessons from a Survey of Crowdworkers (March 1, 2016). Comparative Labor Law \& Policy Journal, Vol. 37, No. 3, 2016. Available at SSRN: https://ssrn.com/abstract=2740940; Paul Secunda, Uber Retirement (January 5, 2017). University of Chicago Legal Forum, Vol. 2017, No. 1, 2017; Marquette Law School Legal Studies Paper No. 17-1. Available at SSRN: https://ssrn.com/abstract=2894566.

${ }^{14}$ David S. Mitchell, Building a More Robust and Inclusive U.S. Retirement System Amid a Changing Economy, The Aspen Institute Financial Security Program (Sept. 2017), https://assets.aspeninstitute.org/content/uploads/2017/09/2017_RETIREMENT-SAVINGS-REPORT-Web.pdf
} 
This paper provides new insight into the Social Security implications of the on-demand economy work by using the Census Bureau's redesigned Survey of Income and Program Participation (SIPP) ${ }^{15}$ to estimate the populations and earnings of self-employed, non-employer workers working outside of a traditional employment relationship ("independent contractors"), ${ }^{16}$ as well as individuals working in occupations that occur in the on-demand economy ("ondemand workers"). ${ }^{17}$

SIPP data can supplement other existing government data sets for federal tax policy purposes because of the large number of individuals surveyed, the reporting of earnings, and the collection of demographic information. In addition, SIPP has the ability to capture individuals not otherwise represented in other government surveys and products of on-demand economy workers because SIPP is able to measure multiple on-demand and independent contract arrangements. SIPP data has the potential to capture non-employee workers earning income

\footnotetext{
${ }^{15}$ Data on business ownership and individual earnings can be obtained through a number of Census products. See Part II infra. One of the main surveys to measure this data is SIPP, which is conducted in a series of national panels, with sample sizes ranging from approximately 14,000 to 36,700 interviewed households. The duration of each panel lasts one year. SIPP is third largest household survey administered by Census, focused on providing accurate and comprehensive information about the income and program participation of individuals and households in the United States. The re-engineered 2014 SIPP survey provides a unique analysis other products do not capture. Specifically, it measures self-employment and participation in concurrent employment measured by industry and occupation. Additionally, it provides analysis on the amount of income derived from each type of employment. Because of this unique ability, SIPP provides a foundation to estimate the number of self-employed individuals, the number of self-employed individuals in particular industries and occupations, and the amount of income that these individuals derive from these types of employment. As with any survey, there are some limitations with these estimates. The data is self-reported, meaning that individuals can incorrectly report their self-employment status, their occupation or industry, and the amount of income that they derived from these employment relationships. ${ }^{16}$ Using SIPP data, we define "Independent Contractors" as respondents who stated that they were self-employed with no employees or owned their own business instead of being employed by another employer or in an "other work arrangement" for their type of work arrangement. This definition excludes individuals employed by an employer or in an "other work arrangement, with no employees, in specified occupations. Variables EJB1_JBORSE through EJB7_JBORSE in the 2014 Panel Wave 2 Metadata, located at: https://www2.census.gov/programssurveys/sipp/data/datasets/2014/w2/2014SIPP_W2_Metadata_AllSections.pdf

${ }^{17}$ Using SIPP data, we define "on-demand workers" as individuals employed by an employer or in an "other work arrangement, with no employees, in specified occupations including babysitting and child care services; dog walking; house sitting; disabled adult or eldercare services; house cleaning; house painting; yard work; property maintenance work; other personal services work such as running errands or helping people move; jewelers; or driving. Dummy variable created by merging EJB1_JBORSE through EJB7_JBORSE, variables TJB1_EMPB through TJB7_EMPB, and selected occupations in TJB1_OCC through TJB7_OCC in the 2014 Panel Wave 2 Metadata, located at: https://www2.census.gov/programssurveys/sipp/data/datasets/2014/w2/2014SIPP_W2_Metadata_AllSections.pdf One of the limitations of using SIPP data is that this definition is too broad in that it could include employees of employers. In addition, the Census SIPP experts we consulted in indicted this definition could include individuals who identified as employees, despite the fact they were actually independent contractors. In addition, this definition is too narrow in that it does not include occupations occurring in the On-Demand Economy such as renting rooms, cars or other assets.
} 
using on-demand platforms to connect with customers and process payment ("on-platform workers") as well as non-employee workers earing income in occupations occurring in the ondemand economy not using on-demand platforms ("off-platform workers"). Most importantly for purposes of this project, SIPP provides data to enable us to estimate the amount of income derived from these work arrangements. ${ }^{18}$

However, SIPP does have its limitations, and the estimates in this paper are supplemental illustrative estimates designed to add to the existing literature on Social Security implications of the tax compliance of these self-employed workers. ${ }^{19}$ For example, the SIPP survey data on selfemployment does not specifically identify individuals who earn income working with ondemand platforms. Instead, we have identified individuals with occupations occurring in the ondemand economy as reflected by their SIPP survey responses. As such, our estimates of ondemand workers include both on-platform workers and off-platform workers, a population that is likely larger than the on-demand platform workforce. ${ }^{20}$ In addition, our estimates on the earnings of both populations are not necessarily net of expenses and are nevertheless understatements of the collective earnings of the populations of independent contractors and ondemand workers we identified using SIPP. ${ }^{21}$

Notwithstanding these data limitations, this paper extends the existing research on the SE tax compliance of independent contractors and on-demand workers by focusing on the Social

\footnotetext{
${ }^{18}$ A more in-depth discussion of the advantages of SIPP to supplement other government surveys is discussed in the Methodology section infra.

${ }^{19}$ As with any survey, there are some limitations that will impact the estimates we calculated using SIPP data. The data is self-reported, meaning that individuals can incorrectly report their self-employment status, their occupation or industry, and the amount of income that they derived from these employment relationships. SIPP has its advantages over other estimates because it is able to capture respondents' data on multiple employment points and is not limited to questions on an individual's main job or primary source of income.

${ }^{20} \mathrm{We}$ recognize that the criteria we used to identify Independent Contractors and on-demand workers to extrapolate earnings and demographic data from the SIPP are imprecise measures of the total population of these self-employed workers. For example, the Census SIPP experts we consulted in connection with this work indicated that while our estimates on the population of on-demand workers were potentially over-inclusive, the measures we used to extrapolate the collective earnings of independent contractors and on-demand workers were too conservative. In order to provide additional context for our estimates using SIPP data, we included additional estimates using the most recent data on alternative contingent workers and gig economy workers available from the U.S. Department of Labor Bureau of Labor Statistics (BLS) as well as the JMPCI 2018 Study. See Table 3 infra.

${ }^{21}$ According to the Census SIPP experts we consulted, the earnings variables we used understated the total amount of earnings of independent contractors and on-demand workers because we only included earnings for people who reported gross total amounts that they actually received during the year. Some SIPP respondents included in our Independent Contractor and On-Demand Worker populations may have reported their earnings another way (such as their average monthly or bi-weekly income, for example), and the measure we used would not include their earnings at all.
} 
Security implications of the failure of these taxpayers to accurately report income and pay SE taxes on this income and considers corresponding demographic data with respect to these populations of workers. In addition, this paper makes policy recommendations to aid with independent contractor tax compliance generally, and more specifically, with on-demand workers to address the SE tax underreporting we estimated.

Part I summarizes the relevant SE tax, filing and information reporting rules and the corresponding tax compliance issues of both independent contractors and on-demand workers. Part II introduces the existing challenges of measuring independent and on-demand economy workers, and provides new estimates on independent contractors and on-demand workers to supplement the existing literature using SIPP data. Part III, relying on SIPP data, estimates how much income independent contractors and on-demand workers earned in 2014.

Part IV approximates the amount of SE taxes that should have been paid on this income and estimates the approximate Social Security underpayment amount using information from the U.S. Treasury's Inspector General for Tax Administration's analysis of underreporting of SE taxes and information gained from research on on-demand economy platforms and the IRS about issuance of tax reporting forms. Part V, utilizing SIPP, examines the demographic make-up of independent contractors and on-demand workers and estimates the impact of failing to report self-employed income on Social Security in 2014, and discusses the potential long-term implications. Finally, Part VI makes policy recommendations targeted to increase the tax compliance of independent contractors and on-demand workers by modernizing information reporting, updating timing requirements for estimated payments, and developing distribution information on the tax requirements for independent contractors and on-demand economy workers on the payment of self-employment taxes.

\section{Background on Tax and Reporting Rules for Independent Contractors and On-Demand Workers}

The U.S. tax system is a pay-as-you go system of tax collection. Since World War II, employees have had a portion of their wages withheld by their employers and remitted to the IRS in anticipation of an employees' annual income and payroll (e.g., Social Security and Medicare 
taxes) tax liability. ${ }^{22}$ Originally enacted as a means to raise revenue to fund increased government operations during wartime, the point of employee tax withholding is to "smooth after-tax income through the year and facilitate revenue collection by the IRS.",23

However, independent contractors and on-demand workers are not generally treated as “employees" for U.S. tax purposes, and, instead, are treated as self-employed for tax purposes with respect their earnings. ${ }^{24}$ As a result, these workers are not generally subject to employer income and payroll tax withholding. Instead, these taxpayers are required to make estimated income tax payments to federal and state tax collection agencies and "when annual net earnings are at least $\$ 400,15.3$ percent in self-employment tax." 25

A consequence of the absence of withholding is underreporting of taxes by a significant number of self-employed taxpayers, who have "different pain points than their employee counterparts with respect to their tax filings." ${ }^{26}$ Government and academic research on the tax compliance of the self-employed reflect these challenges and "there is a large literature showing that this group consistently and substantially underreports their income to tax authorities."27

\footnotetext{
${ }^{22}$ Seth D. Harris \& Alan B. Krueger, A Proposal for Modernizing Labor Laws For Twenty-First-Century Work: The "Independent Worker." The Hamilton Project, Discussion Paper 2015-10 (Dec. 2015), http://www.hamiltonproject.org/assets/files/modernizing_labor_laws_for_twenty_first_century_work_krueger_harri s.pdf (last visited Sep 10, 2018).

${ }^{23} \mathrm{Id}$. at 18 .

${ }^{24}$ For a discussion on worker classification and its relevance to on-demand workers and U.S. tax rules, see Annette Nellen, Caroline Bruckner \& Jennifer Brown, "Taxes and the Growing Gig Workforce: What to Know." 128 JournAL OF TAXATION 6 at 15 (June 2018) ("Nellen, Bruckner \& Brown JOT"). A primary reason for why policymakers, tax and labor experts, and on-demand platforms have been slow to tackle the simmering tax and compliance issues underlying the On-Demand Economy is the looming question of whether workers who provide services for customers via on-demand platforms are misclassified employees. Misclassification issues have long stymied Congressional efforts to address tax and benefits issues of self-employed workers, who are the smallest of small business owners. Rarely have policymakers been able to reach consensus on strategies to address worker misclassification for either tax or labor law purposes. With the advent of the tech-enabled On-Demand Economy and the at least 2.3 million taxpayers now earning income selling goods and services through on-demand platforms every month, Congressional action to address tax compliance challenges of these taxpayers could be the top priority, separate and apart from resolving any corresponding worker misclassification issues. See Caroline Bruckner, Response to Questions for the Record in Connection with U.S. Senate Committee On Finance Subcommittee on Taxation and IRS Oversight July Hearing, (Sept. 19, 2018), on file with author (responding to question from Sen. Thune as to whether resolving misclassification of on-demand workers could be a legislative priority).

${ }^{25}$ Financing of the Social Security program is authorized by the revenue collected pursuant to: (i) the Federal Insurance Contributions Act (FICA), which applies to employers and employees; and (ii) the Self-Employment Contributions Act, which applies to self-employment income. CRS Report R42035, supra n. 11 at 3.

${ }^{26}$ Bruckner, supra n. 1 at 9.

${ }^{27}$ Hurst, Erik and Li, Geng and Pugsley, Benjamin W., Are Household Surveys Like Tax Forms: Evidence from Income Underreporting of the Self Employed (November 2010). NBER Working Paper No. w16527. Available at SSRN: https://ssrn.com/abstract=1708769
} 
More recently, a 2018 tax preparer industry survey found that 32 percent of self-employed workers admitted to underreporting their income for tax purposes while 36 percent 'don't do taxes at all." 28

With respect to the payment of SE tax, the amount and timing requirements of quarterlyestimated payments, as well as the information reporting regime for on-platform work create tax compliance challenges that often trigger non-filing, under-and non-payment of taxes - in many cases, unwittingly by taxpayers who are unfamiliar with paying taxes on self-employment income. ${ }^{29}$ In fact, anecdotal evidence from tax preparers advising independent contractors and on-demand economy workers suggests that while these taxpayers are generally aware that they may owe income taxes on their earnings, many are surprised to learn they owe SE taxes, too. ${ }^{30}$

\section{The SE Tax}

Unlike traditional employees, who are subject to payroll taxes and withholding by employers that also pay a portion of employees' payroll taxes, taxpayers with self-employment income pay the combined employee and employer shares of Social Security and Medicare taxes (i.e., 15.3 percent in SE tax, which is 12.4 percent Social Security tax on up to $\$ 128,400$ on net earnings and a 2.9 percent Medicare tax on their entire net earnings) pursuant to the SelfEmployment Contributions Act (SECA). ${ }^{31}$ Any taxpayer with net earnings of $\$ 400$ of selfemployment income is required pay SE tax and file a Schedule SE. ${ }^{32}$ Although self-employed taxpayers pay the combined employer and employee share of Social Security and Medicare taxes, they are allowed a deduction of one-half of their total SE tax paid for federal income tax purposes. $^{33}$

\footnotetext{
${ }^{28}$ CPA Practice Advisory, "32\% of Self-Employed Workers Admit They Under Report Taxable Income." (April 24, 2018), https://www.cpapracticeadvisor.com/news/12409241/32-of-self-employed-workers-admit-they-under-reporttaxable-income (last visited Sept. 15, 2018). Of the 36 percent of respondents who didn't pay taxes at all, 9 percent admitted to not having a reason, 17 percent claimed to not make enough to owe taxes, and the remaining 10 percent answered they had losses that exceeded their profits. Id.

${ }^{29}$ Bruckner, supra $\mathrm{n} .1$ at 9-11.

${ }^{30} \mathrm{Id}$.

${ }^{31}$ CRS Report R42035, supra $\mathrm{n} .11$ at 3 . Specifically, employees and employers each pay 6.2 percent Social Security tax on up to $\$ 128,400$ of earnings in 2018 and an additional 1.45 percent Medicare tax on all earnings (i.e., the two components add up to 7.65 percent in tax paid by employees and then 7.65 percent paid by employers).

${ }^{32}$ IRS, Self-Employment Tax (Social Security and Medicare Taxes), (2018), https://www.irs.gov/businesses/smallbusinesses-self-employed/self-employment-tax-social-security-and-medicare-taxes

${ }^{33} I d$.
} 
Together with federal income tax, SE tax can add up quickly for independent contractors and on-demand workers, and can create significant tax compliance issues. ${ }^{34}$ For example, in a 2015 survey on the tax compliance challenges of on-platform workers, almost 43 percent of surveyed respondents did not set aside any money and were not aware of how much they would owe on income earned from working with an On-Demand Platform as a service provider or seller. ${ }^{35}$

\section{Quarterly Estimated Payments}

It's not only the amount of income and SE taxes owed that trip up taxpayers with selfemployment income when it comes to filing taxes, it's also the timing of when to pay ${ }^{36}$ Under current tax rules, when self-employed taxpayers are expected to owe at least $\$ 1,000$ in taxes and aren't subject to withholding, advance payments of estimated tax are due to the IRS in quarterly installments. ${ }^{37}$ These payments are due on April 15, June 15, Sept. 15 and Jan. 15 and are referred to as quarterly estimated payments. ${ }^{38}$

In calculating whether a taxpayer needs to make quarterly estimated payments throughout the year, taxpayers need to include both income taxes and self-employment taxes owed—minus any refundable credits — on any income not subject to withholding. ${ }^{39}$ Added together, income tax and self-employment tax liabilities for independent contractors and on-demand workers can quickly reach the $\$ 1,000$ threshold for triggering quarterly estimated payments. For example, a ridesharing driver who earns $\$ 7,500$ driving part-time for an On-Demand Platform and earns no other income would have a SE tax liability of $\$ 1,060$ triggering a required filing of estimate payments even if no income tax is owed. ${ }^{40}$

\footnotetext{
${ }^{34}$ Bruckner, supra n. 1 at 11 . However, with respect to On-Demand Economy workers who earn income from home-sharing or real property rental activities, the tax reporting rules are more complicated. For example, most individuals with rental income report that income and expenses on a Schedule E and are not subject to SECA tax on that income; however, certain real estate professionals who earn rental income may be required to file a Schedule C and be subject to SE tax. See EY, "General Guidance on the Taxation of Income." Airbnb Resources for the 2017 U.S. Tax Season (Jan. 2017), https://assets.airbnb.com/eyguidance/us.pdf

${ }^{35}$ Bruckner, supra $\mathrm{n} .1$ at 12.

${ }^{36} \mathrm{Id}$.

${ }^{37}$ IRC $\S 6654$.

${ }^{38} I d$.

${ }^{39}$ See IRS Form 1040 ES, https://www.irs.gov/pub/irs-pdf/f1040es.pdf.

${ }^{40}$ Nellen, Bruckner \& Brown JOT, supra n. 24 at 15.
} 
Moreover, survey data of suggests that many taxpayers are unaware of the requirements of quarterly estimated payments. For example, a 2015 survey of experienced self-employed taxpayers found that one-third of survey respondents earning income in the on-demand economy reported not knowing whether or not they were required to file quarterly estimated payments with the IRS. ${ }^{41}$

\section{Information Reporting Requirements}

Lack of information and understanding of what is required for tax compliance purposes is a common complaint among self-employed taxpayers. ${ }^{42}$ In terms of calculating taxes and reconciling income, employees who have income and payroll taxes withheld and remitted to the IRS by their employers, receive an IRS Form W-2 from their employers to use to fill out their tax returns in April. In contrast, self-employed taxpayers who pay income and SE taxes via quarterly-estimated payments are subject to a separate set of information reporting rules and forms for non-employee compensation (e.g., the IRS Forms 1099) that are reported to the IRS by payers and third-party settlement organizations. ${ }^{43}$ However, on-demand workers who are onplatform workers are not as likely to have their income reported to the IRS. ${ }^{44}$ Under the current tax reporting rules for income of on-platform workers, odds are slim that these workers will receive any Form 1099 to file their taxes. ${ }^{45}$

Generally, self-employed workers are supposed to receive a Form 1099-MISC for payments by businesses for more than $\$ 600$ for goods or services that they provide. ${ }^{46}$ However, if a self-employed worker receives payments from customers via an On-Demand Platform, then the IRS generally considers the On-Demand Platform to be a third-party settlement organization (TPSO) for tax reporting purposes. ${ }^{47}$ This matters because a TPSO isn't required file a Form 1099-K with the IRS or send a copy to a service provider or seller unless the aggregate number

\footnotetext{
${ }^{41}$ Bruckner, supra $\mathrm{n} .1$ at 11.

${ }^{42} I d$. at 12 (noting that more than one-third of survey respondents did not understand record-keeping requirements for tax purposes).

${ }^{43} I d$. at 9.

${ }^{44} I d$.

${ }^{45} I d$.

${ }^{46}$ IRC $\S 6041$.

${ }^{47}$ See Ltr. Ruls. 201604003; 201619006; 201719009; 201836008.
} 
of transactions of a service provider or seller exceeds 200 and the amount reported exceeds $\$ 20,000$ (the "200/\$20K Form 1099-K Threshold"). ${ }^{48}$

Most on-demand platforms use the 200/\$20K Form 1099-K Threshold for providing Form 1099-Ks to service providers and sellers, which is consistent with IRS filing requirements, rather than the $\$ 600$ Form 1099-MISC threshold. ${ }^{49}$ Adoption of the higher threshold by most on-demand platforms, although consistent with current IRS reporting requirements, results in fewer Form 1099-Ks being sent to workers and the IRS due to the fact that most on-platform workers do not earn amounts in excess of $\$ 20,000$ to trigger the 200/\$20K Form 1099-K Threshold. ${ }^{50}$ Some survey research found as few as 32 percent of on-platform workers received a Form 1099-MISC or Form 1099-K in 2015. ${ }^{51}$

More recently, in 2018, an analysis prepared by the State of California's Franchise Tax Board (the "California Tax Analysis") found that of the Top 100 on-demand platforms in 2016, only 12 percent issued Form 1099-Ks to service providers, and that of the 12 percent who did send Form 1099-Ks to their workers, only half issued more than 55. ${ }^{52}$ At the same time, the California Tax Analysis found that companies issuing Form 1099-K had grown in volume by 163 percent, but that workers receiving Form 1099-Ks had only increased by 26 percent. ${ }^{53}$ The 2016 data points included in the California Tax Analysis reflect the underlying reality of the impact of the current information reporting rules for on-demand platform workers: the majority of sellers and service providers earning income doing on-platform work do not receive any Form 1099-K, which means the IRS doesn't either. ${ }^{54}$

Consequently, efforts to quantify the population of independent contractors and, specifically, the on-demand platform workforce using information reporting filings (i.e., Forms

\footnotetext{
${ }^{48}$ IRC $\S 6050 \mathrm{~W}$.

${ }^{49}$ Bruckner Senate July 2018 Testimony, supra n. 9 (noting that most platforms do not send 1099-Ks for earnings unless the 200/\$20K Form1099-K Threshold is met, although Lyft is a notable exception). In prior years, Lyft did not send their drivers 1099-Ks unless the 200/\$20K Form 1099-K Threshold had been triggered. Following the release of Shortchanged in 2016, Lyft began to provide all drivers Form 1099-Ks once at least $\$ 600$ from rides had been paid by customers.

${ }^{50}$ Id. See also, Bruckner, supra n. 1.

${ }^{51}$ Bruckner, supra $\mathrm{n} .1$ at 10.

${ }^{52}$ Rosita Mindermann \& Alexander Escobar, "Gig Economy Management Development Program Project." State of California Franchise Tax Board (Sept. 21, 2018), https://www.ftb.ca.gov/law/meetings/09212018/3.pdf (last visited Sept. 15, 2018).

${ }^{53} \mathrm{Id}$.

${ }^{54}$ Bruckner Senate July 2018 Testimony, supra n. 9.
} 
1099), can be particularly challenging. ${ }^{55}$ In fact, some experts have concluded that although the Form 1099-K has been used since 2011 to report settlement of payment card transactions or settlement of third-party network transactions, it is "relatively unusual" for self-employed individuals to receive a Form 1099-K, and "most are not issued to unincorporated self-employed individuals." ${ }^{56}$ Nonetheless, while self-employment earnings may (or may not be) subject to information reporting, taxpayers who earn income for services provided are expected to report those payments on Schedule C of their Form 1040, "even if the individual received no information returns in connection with their taxable earnings and even if their business expenses fully offset the gross payments received." 57

\section{Sizing Up the Problem: Estimates on the Size of the Independent Contractor and On- Demand Workforce}

While there is consensus that self-employed taxpayers have tax compliance and underreporting issues, the size of population of independent workers and the on-demand economy workforce has been the subject of much debate in recent years. The fundamental problems is that "different data sources provide different answers to the simple question of what is the level and trend of self-employment in the U.S. economy." 58 In addition, "although traditional (offline) informal paid work has always been part of the labor sector, the rise of online enabled paid work activities requires new approaches to measure this growing trend." ${ }^{29}$ Put

\footnotetext{
${ }^{55}$ See Emilie Jackson, Adam Looney \& Shanthi Ramnath, "The Rise of Alternative Work Arrangements: Evidence and Implications for Tax Filing and Benefit Coverage." (June 2018), https://www.census.gov/content/dam/Census/about/about-the bureau/adrm/FESAC/meetings/Ramnath\%20Presentation.pdf (reviewing the findings from their 2017 paper of the same name and noting that a "large fraction of people with SE income did not receive a 1099-MISC and very few people receive a 1099-K."). See also, the Oct. 2015 letter from U.S. Treasury to Sen. Mark Warner explaining why publicly-available taxpayer filings "do not provide a good measure of contingent workforce or independent contractor income, let alone the on-demand economy." Letter from the U.S. Department of the Treasury to Sen. Mark Warner (Oct. 27, 2015) TaxAnalysts Doc 2015-25376.

${ }^{56}$ Katherine G. Abraham, John C. Haltiwanger, Kristin Sandusky \& James R. Spletzer, "Measuring the Gig Economy: Current Knowledge and Open Issues.” NBER Working Paper 24950 (Aug. 2018), http://www.nber.org/papers/w24950.pdf (the "NBER WP 24950").

${ }^{57} I d$.

${ }^{58} \mathrm{Id}$. at 15 .

${ }^{59}$ Barbara Robles \& Marysol McGee (2016). "Exploring Online and Offline Informal Work: Findings from the Enterprising and Informal Work Activities (EIWA) Survey," Finance and Economics Discussion Series 2016-089. Washington: Board of Governors of the Federal Reserve System, https://doi.org/10.17016/FEDS.2016.089 The EIWA Survey defined on-demand works as "task-for-fee work, renting and selling used items, and other informal work activities among households both online and offline." Id.
} 
simply, measuring workers with self-employment income subject to SE tax-including both OnPlatform and off-platform workers - can be challenging.

\section{Government Efforts to Measure Independent Contractors and On-Demand Workers}

Even in circumstances where government measures have endeavored to measure the population and earnings of independent contractors or on-demand platform workers, there are practical impediments that can skew results such as definitional challenges or the kinds of data used. ${ }^{60}$ For example, a recent U.S. Government Accountability Office (GAO) analysis of the state of measuring the contingent work illustrated the difficulty in measuring these populations because estimates, "can range anywhere from 5 percent of the workforce to more than one-third of the total employed labor force, depending the definition of contingent work and the data source." ${ }^{61}$

A more recent analysis from the U.S. Treasury's Office of Tax Analysis (OTA), using administrative tax records, found that in 2014, only a small group — 109,700 individuals—filed a tax return reporting income from earning income from an On-Demand Platform. ${ }^{62}$ At the same time, OTA acknowledge that the total count of gig workers was "likely to be an undercount of the true number of individuals in that participated in the 'gig economy' because some participants may not have filed a return or not filed a Schedule C reporting that income; because some platforms firms do not provide 1099s to all of their participants; and also because not all prominent service providers could be found in the data." ${ }^{63}$

The most recent illustration of the definitional challenges associated with trying to measure these populations is the 2018 U.S. Bureau of Labor Statistics (BLS) survey of alternative contingent workers, which found that 6.9 percent of the workforce, or approximately

\footnotetext{
${ }^{60}$ See e.g., Office of Tax Analysis, OTA Working Paper 114, The Rise of Alternative Work Arrangements: Evidence and Implications for Tax Filing and Benefit Coverage (Jan. 2017), https://www.treasury.gov/resource-center/taxpolicy/tax-analysis/Documents/WP-114.pdf (last visited Sept. 15, 2018) (“OTA Working Paper 114”).

${ }^{61}$ U.S. Gov’t Accountability Office, GAO-15-168R, Contingent Workforce: Size, Characteristics, Earnings, and Benefits, (April 20, 2015), https://www.gao.gov/assets/670/669899.pdf

${ }^{62}$ OTA Working Paper 114, supra n. 60 at 16.

${ }^{63} \mathrm{Id}$. at 15 . The IRS developed the Form $1099-\mathrm{K}$ for submission by payers starting in 2012 for reportable payments made in 2011. U.S. Treasury Inspector General for Tax Administration, The Internal Revenue Service is Underutilizing Form 1099-K Data to Identify Tax Returns for Audit, Reference Number: 2017-30-083 (Sept. 29, 2017), https://www.treasury.gov/tigta/auditreports/2017reports/201730083fr.pdf
} 
10.6 million individuals, were independent contractors. ${ }^{64}$ Importantly, this measure applied only where an alternative or contingent work arrangement was a person's "sole or main job," and therefore excluded the majority of on-platform workers who provide services and goods as a secondary, rather than primary, source of income. ${ }^{65}$ In an effort to capture this population, in September 2018, BLS released updated survey results on four questions included as part of the 2017 BLS ACW Survey designed to specifically to gauge "gig economy" participation and found that in May 2017, approximately 1.6 million workers did work for an on-demand platform (the "2017 ACW Gig Economy Supplement"). ${ }^{66}$ Notably, the 2017 ACW Gig Economy Supplement measured far fewer on-demand platform workers than other, more expansive studies, had counted. Also, BLS indicated that the questions used to measure gig workers did not work as intended and that going forward, BLS would "not again attempt to collect data about electronically mediated work using the four new questions fielded in the May 2017."67

\section{Non-Government Measures of On-Demand Platform Workforce}

In addition to government measures, there are various non-government and private sector surveys, estimates and projections on the size and scope of independent workers. Differences in definition mean different results. For example, McKinsey Global Institute found in 2016 that approximately 27 percent of the workforce, or 68 million individuals, was engaged in independent contract work. ${ }^{68}$ That same study also found that at least 15 percent of the independent workers they surveyed have used a digital platform to find work and that the "socalled on-demand economy is growing rapidly." 69 Other private sector surveys have found comparably large contingencies of independent contractors. For example, Upwork and the

\footnotetext{
${ }^{64}$ Bureau of Labor Statistics, Contingent and Alternative Employment Arrangements - May 2017, U.S. Dept. of Labor (June 7, 2018), https://www.bls.gov/news.release/pdf/conemp.pdf (announcing results of a 2017 BLS survey of contingent workers and independent contractors - the first time this survey had been conducted since 2005) (the “2017 BLS ACW Survey"). The 2017 BLS ACW Survey also identified 2.6 million on-call workers, 1.4 million temporary help agency workers, and 933,000 contract workers. Id.

${ }^{65} I d$.

${ }^{66}$ Current Population Survey staff, "Electronically mediated work: new questions in the Contingent Worker Supplement," Monthly Labor Review, U.S. Bureau of Labor Statistics, September 2018, https://doi.org/10.21916/mlr.2018.24

${ }^{67} I d$.

${ }^{68}$ McKinsey \& Company, "Independent Work: Choice, Necessity, and the Gig Economy.” (Oct. 2016) https://www.mckinsey.com/featured-insights/employment-and-growth/independent-work-choice-necessity-and-thegig-economy (last visited Sep 9, 2018).

${ }^{69} I d$.
} 
Freelancer's Union conducted a survey in 2017 that found that 36 percent of the workforce or approximately 57.3 million individuals were employed as independent contractors. ${ }^{70}$ In 2018 , MBO Partners, in their annual survey of the independent workforce found that 42 million individuals were independent contractors. ${ }^{71}$

In terms of measuring the on-demand economy specifically, the Aspen Institute and Time's conducted a survey in 2015 that found approximately 22 percent, or 45 million individuals, have participated in the on-demand economy as a worker. ${ }^{72}$ In 2016, former Chief Economist at the U.S. Department of Labor Lawrence Katz and former Chair of the White House Counsel of Economic Advisors under President Obama, Alan Krueger, published a paper estimating that 0.5 percent of all workers participated in the on-demand economy. ${ }^{73}$

Most recently, in September 2018, J.P. Morgan Chase Institute updated their landmark 2016 study on the on-demand economy and concluded 2.3 million families with Chase checking accounts engage every month in on-platform work, and that 5.5 million households have income every year. ${ }^{74}$ The JPMCI 2018 Study is particularly important and serves as a benchmark for measuring on-platform work participation both because it relies on actual income flowing into on-platform workers bank accounts (as opposed to survey responses or tax filings) and because it includes data from 2012 through 2018 - a period of extraordinary growth for this sector.

\section{SIPP Data Measuring Independent Contractors and On-Demand Workers}

Although not as robust as the JPMCI 2018 Study, SIPP data can provide significant insight into the population of self-employed workers. For example, using SIPP data, we found that 7.1 million respondents identified as self-employed small businesses with no employees, which we defined as independent contractors, ${ }^{75}$ and we identified 3.12 million on-demand

\footnotetext{
${ }^{70}$ FIA 2017 Report, supra n. 5.

${ }^{71}$ MBO 2018 Report, supra n. 4.

${ }^{72}$ Catherine Sullivan Burson-Marsteller, Forty-Five Million Americans Say They Have Worked in the On-Demand Economy, While 86.5 Million Have Used It, Aspen Institute, n. 11 (Jan. 6, 2016), http://www.aspeninstitute.org/news/2016/01/06/forty-five-million-americans-say-they-have-worked-demandeconomy-while-865-million

${ }^{73}$ Lawrence F. Katz \& Alan B. Krueger, The Rise and Nature of Alternative Work Arrangements in the United States, 1995-2015, (Mar. 29, 2016), http://scholar.harvard.edu/files/lkatz/files/katz_krueger_cws_v3.pdf?m=1459369766 Notably, this paper did not include accommodation sharing (e.g., Airbnb hosts), which are included in other major studies.

${ }^{74}$ JPMCI 2018 Study, supra n. 2.

${ }^{75}$ See supra notes $15-17$ and accompanying text.
} 
workers participating in occupations occurring in the on-demand economy, which would include both On-Platform and off-platform work. ${ }^{76}$

However, these results are not entirely consistent with the findings of the JPMCI 2018 Study, which looked at 39 million bank accounts with deposits from 128 on-demand platforms. For example, SIPP did not specifically track electronically mediated or on-platform work, so our estimates rely on approximations of occupations occurring in the on-demand economy. In addition, the SIPP data we used to measure on-demand workers did not include occupations in the leasing of assets and generating rental income, which were included in the JPMCI 2018 Study.

At the same time, our review of SIPP data finds that independent contractors and OnDemand combined represented approximately 10.22 million workers. To provide context for this finding, consider that the 2017 BLS ACW Survey identified 10.6 million workers as independent contractors, and another 1.6 million working as on-platform workers. ${ }^{77}$

\section{Earnings of Independent Contractors and On-Demand Workers}

Similar to the discrepancies and disparities in the government and private measurement of the size of the independent contract and on-demand workforce, there is little consensus on the average or median amounts of income earned by these groups of workers. However, the work that has been done on these issues does regularly suggest that, in general, independent contractors earn more income than on-platform workers earn.

\section{Private Sector Estimates of Earnings of On-Demand Workforce}

For example, MBO Partners in 2018 found that the average income for full-time independent contractors was $\$ 69,100$, and that just over one-in-five full-time independent contractors made more than $\$ 100,000 .{ }^{78}$ And, the Upwork and the Freelancers Union found that more than one-third (36 percent) of freelancers made more than $\$ 75,000$ in $2017 .{ }^{79}$

\footnotetext{
${ }^{76} \mathrm{Id}$.

772017 BLS ACW Survey, supra n. 64.

${ }^{78}$ MBO 2018 Report, supra n. 4 at 8.

${ }^{79}$ FIA 2017 Report, supra n. 4 at Slide 42.
} 
In terms of earnings of on-platform workers, the JPMCI 2018 Study finds that "platform earnings represent a major source of income for families during the months they participate in the on-demand economy, but just 20 percent of income among those who have participated at any point over the prior year." 80 This research suggests that on-platform workers, unlike independent contractors, do not typically do on-platform work for their sole-source of income and most participants "are active in just a few months out of the year." 81

Average monthly earnings for on-platform workers ranged from $\$ 608$ (selling goods) to $\$ 1,736$ (leasing assets), with the majority of these workers earning monthly income averaging $\$ 783$ providing transportation services. ${ }^{82}$ This cycling in and out of the on-platform work or "churn" means that annualizing the monthly earnings on on-platform workers is not an accurate measure of annual earnings of these workers.

\section{SIPP Estimates of Independent Contractor and On-Demand Worker Earnings}

However, SIPP provides additional insight into the collective earnings of independent contractors and on-demand workers, which, in turn, can provide further insight as to the Social Security implications for these populations. Using data from SIPP, we found that individuals who were independent contractors reported that they earned, collectively, approximately \$204.1 billion dollars in income in 2014 from these employment relationships and on-demand workers collectively earned approximately $\$ 35.97$ billion dollars in income from these employment relationships in $2014 .{ }^{83}$ Although our population estimates of on-demand workers may be overinclusive, our estimates of their earnings are certainly conservative and a likely underestimate of the collective earnings of on-demand workers. That noted, these estimates, while not an approximation for taxable income, can be used to gauge the underpayment of SE tax and Social Security contributions of these populations.

\footnotetext{
${ }^{80}$ JPMCI 2018 Study, supra n. 2 at 7.

${ }^{81} \mathrm{Id}$. at 6.

${ }^{82} \mathrm{Id}$. at 14.

${ }^{83}$ Sum of income reported by independent contractors and on-demand workers by tabulating applicable TJB1_GAMT1 through TJB7_GAMT variables in the 2014 Panel Wave 2 Metadata, located at: https://www2.census.gov/programs-surveys/sipp/data/datasets/2014/w2/2014SIPP_W2_Metadata_AllSections.pdf; see also supra note 21 and accompanying text.
} 


\section{Estimates of Under-Reported Self-Employment Tax Should Have Been Collected from}

\section{Independent Contractors and On-Demand Workers}

Our ability to extrapolate from SIPP the number and earnings of independent contractors and on-demand workers is foundational to our estimate of the corresponding SE tax underpayment by these taxpayers and ability to translate those amounts to Social Security contributions. By utilizing underreporting estimates derived from government research and tax gap analysis, prior work on tax compliance specific to SE taxes, and the likely misreporting of income due to current information reporting rules, we are able to approximate an estimate of the amount of underreported SE tax on the earnings of the independent contractors and on-demand workers we identified using SIPP data.

In addition, we are able to translate our estimate to the amount of Social Security contributions that should have been paid on these workers earnings. For purposes of this analysis, we assume all unreported earnings would be subject to SE taxes and that all workers earned less than $\$ 128,400$. However, additional context is appropriate for understanding how and why we developed the methodology we did for our estimates. To that end, background on the tax gap and the existing work that has been done on SE tax compliance is provided below. Our estimates are not intended to be comparable to estimates developed by Congressional estimators or other government projections.

\section{The Tax Gap and Underreported Self-Employment Taxes}

IRS performs a regular study that estimates the gross tax gap, or the difference between the amount of tax that taxpayers should pay for a given year and the amount that is paid. ${ }^{84}$ The tax gap is measured in terms of non-filing, underreporting of income and underpayment of taxes. "Of these three categories, taxpayer underreporting makes up the vast majority of the tax collection shortfall. ${ }^{85}$ In the most recent data, which was published in 2016 for the tax years 2008 to 2010, the IRS found a total underreporting tax gap of \$65 billion of SE tax, and an underpayment tax gap of $\$ 6$ billion of employment tax, and an annual non-filing tax gap of $\$ 4$

\footnotetext{
${ }^{84}$ Janet Holzblatt \& Jamie McGuire, Factors Affecting Revenue Estimates of Tax Compliance Proposals, Joint Working Paper of the Congressional Budget Office and the Staff of the Joint Committee on Taxation, CBO Working Paper 2016-05 (JCX-90-16), (Nov. 2016), https://www.jct.gov/publications.html?func=startdown\&id=4964 ${ }^{85}$ Manoj Viswanathan, Tax Compliance in a Decentralizing Economy (July 13, 2017). Available at SSRN: https://ssrn.com/abstract=3002213 or http://dx.doi.org/10.2139/ssrn.3002213
} 
billion from SE taxes. ${ }^{86}$ Additionally, the IRS estimates that non-reporting of self-employment tax constitutes approximately 1 percent of the non-filing gap, and underreporting of selfemployment tax constitutes 14 percent of the total share of the gross total tax gap. ${ }^{87}$

Importantly, the IRS has found that misreporting of income that is subject to withholding and information reporting is 1 percent, but for where there is no withholding and there is little or no information reporting, instances of misreporting jumps to 63 percent. ${ }^{88}$ As Congressional revenue estimators have noted, noncompliance is greatest for self-employment income "for which third-party information reporting is not separately reported to the IRS and is very difficult to obtain." "Es Essentially, compliance is higher when income is "visible" to the IRS and taxpayers through withholding and information reporting. ${ }^{90}$

\section{Treasury's Prior Work on Underpayment of SE Tax}

In prior years, Treasury had considered strategies for addressing the tax gap through increased audit and new processes to "accurately identify the taxpayers and income that are subject to self-employment taxes." ${ }^{.91}$ In fact, in a 2007 memorandum to the Deputy Commissioner for Services and Enforcement from the U.S. Treasury Deputy Inspector General for Audit (the "Treasury IG") reflected the results of an audit of these strategies to determine how to improve identification of unreported self-employment taxes (the "2007 TIGTA Audit"). ${ }^{92}$ As part of the 2007 TIGTA Audit, the Treasury IG reviewed a statistically valid sample of 138 tax year returns from 2003 with incomes of $\$ 2,000$ or more on a Form 1040 Profit or Loss from Business Schedule C or Profit or Loss from Farming Schedule F, and or line 21 that contained other income, but that did not include a Schedule SE reporting self-employment taxes. ${ }^{93}$

\footnotetext{
${ }^{86}$ Tax Gap Estimates for Tax Years 2008-2010, Internal Revenue Service (April 2016), https://www.irs.gov/PUP/newsroom/tax\%20gap\%20estimates\%20for\%202008\%20through\%202010.pdf (“IRS 2008-2010 Tax Gap Data").

${ }^{87} \mathrm{Id}$.

${ }^{88} \mathrm{Id}$. at 2.

${ }^{89}$ Holzblatt \& McGuire, supra n. 84 at 2.

${ }^{90}$ IRS 2008-2010 Tax Gap Data, supra n. 86 at 2.

${ }^{91}$ Michael R. Phillips, U.S. Treasury Inspector General for Tax Administration, "Identification of Unreported SelfEmployment Taxes Can Be Improved," U.S. Dep't of Treasury, (Oct. 11, 2007), https://www.treasury.gov/tigta/auditreports/2008reports/200830001fr.pdf (last visited Sep 10, 2018).

92 Id.

${ }^{93} \mathrm{Id}$.
} 
Of the 138 returns the Treasury IG reviewed, 52 were selected for audit, 50 audits were completed and five were closed with no change, and 12 had been closed with little or no examination of the returns. But, for the remaining 33 returns (23.91 percent), the examination averaged an additional self-employment tax liability of $\$ 1,818$ per return. Of the 86 returns that had not been selected for audit, 28 appeared to have self-employment tax liabilities (20.29 percent) that averaged an additional self-employment tax liability of $\$ 1,217$ per return. ${ }^{94}$

Estimates for Underreporting of Independent Contractors and On-Demand Workers Using SIPP For purposes developing our estimates on the underpayment of SE tax by independent contractors, we relied on the data developed in the 2007 TIGTA Audit of underpayment of SE tax. Notably, our estimates only approximate the average amount of underpayment of SE tax on average income for the independent contractors we identified using SIPP. To develop an average underpayment amount we could apply to the earnings and populations of independent contractors, we calculated an average using the data from the 2007 TIGTA Audit by adding the 33 audited returns the with additional self-employment tax liability of $\$ 1,818$ and the 28 returns that were appeared to have an estimated $\$ 1,217$ underpayment of self-employment tax liability. This totaled 61 out of 138 returns or 44.2 percent of returns that had an underpayment of SE tax. ${ }^{95}$ Additionally, we averaged the 33 returns with an average of $\$ 1,818$ of additional liability per return with the 28 returns with an average of $\$ 1,217$ per return to approximate an average underpayment of SE tax liability of $\$ 1,542$.

\section{Independent Contractors}

To calculate the amount of independent contractors underreporting self-employment tax liability, we started with the collective earnings of this population for 2014 that we extrapolated from SIPP data, \$204.1 billion, and calculated that the average earnings of these 7.1 million workers were $\$ 28,746.48$. Further, we calculated that the SE tax owed on $\$ 28,746.48$ was

\footnotetext{
${ }^{94} I d$. An additional 6 returns appeared to have SE tax liabilities in excess of $\$ 2,000$. Id. at 3.

${ }^{95}$ Experts we consulted, including James R. White, former U.S. Government Accountability Office (GAO) director of tax research on strategic issues, suggested that a rate of $44.2 \%$ of returns with underpayment of SE Tax was, in fact, too conservative. For example, in 2007, GAO issued a report finding least 61 percent of sole proprietors underreported their net income by $\$ 93.6$ billion in 2001. See, James R. White, Tax Gap: A Strategy for Reducing the Gap Should Include Options for Addressing Sole Proprietor Non Compliance, U.S. Gov't Accountability Office, GAO-07-1014, (July 2007), https://www.gao.gov/assets/270/265399.pdf
} 
$\$ 4,398.21$, but given that average underreporting of SE tax using the 2007 TIGTA report was $\$ 1,542$, we assumed that where underreporting of SE Tax had occurred, it would be approximately 35.1 percent of the amount actually owed.

Using the 2007 TIGTA Audit derived estimate that 44.2 percent of taxpayers with selfemployment income underreported their self-employment income on their Form 1040, we estimated that 3.1 million independent contractors underreported their SE tax. We then calculated that these 3.1 million independent contractors had average earnings of $\$ 28,746.48$, which translated to collective earnings of \$90.21 billion. The amount of SE tax owed on \$90.21 billion was $\$ 13.80$ billion, however, given that there is a 35.1 percent average underreporting of income, we estimated that $\$ 4.84$ billion of SE tax was underreported by independent contractors and in 2014 and that approximately $\$ 3.92$ billion of this amount constituted underreported Social Security contributions. Table 1 summarizes our estimates.

\section{Table 1: Estimate of Underpayment of Social Security Contributions for Independent Contractors Using Treasury Estimates}

\begin{tabular}{|c|c|}
\hline Total Earnings of Independent Contractors in 2014 & \$204.1 Billion \\
\hline $\begin{array}{l}\text { Estimated number of independent contractors from } \\
\text { SIPP \& Average Earnings }\end{array}$ & 7.1 Million/\$28,746.48 Avg. Earnings \\
\hline $\begin{array}{l}2007 \text { TIGTA Audit \% of Returns with } \\
\text { Underpayment }\end{array}$ & $44.2 \%$ \\
\hline 2007 TIGTA Audit Average SE Tax Underpayment & $\$ 1,542$ \\
\hline Average Rate of Underpayment $(\$ 1,542 / \$ 4,398)$ & $35.1 \%$ \\
\hline $\begin{array}{l}\text { Estimated number of independent contractors With } \\
\text { Additional SE Tax Liabilities }\end{array}$ & 3.1 million (7.1 million $\mathrm{x} 44.2 \%$ ) \\
\hline $\begin{array}{l}\text { Total Earnings of Underreporting independent } \\
\text { contractors }\end{array}$ & $\begin{array}{l}\text { \$90.21 Billion (3.1 million } \mathrm{x} \\
\$ 28.746 .48)\end{array}$ \\
\hline $\begin{array}{l}\text { SE Tax Owed on Earnings of Underreporting } \\
\text { independent contractors }\end{array}$ & $\$ 13.80$ Billion $(\$ 90.21 \times 15.3 \%)$ \\
\hline $\begin{array}{l}\text { Estimated amount Underreported SE Tax for } \\
\text { independent contractors }\end{array}$ & \$4.84 Billion ( $\$ 13.80$ Billion $x$ 35.1\%) \\
\hline $\begin{array}{l}\text { Estimated amount of Underpayment of Social } \\
\text { Security }\end{array}$ & $\$ 3.92$ Billion $(\$ 4.8 \text { Billion } \times 81.05 \%)^{96}$ \\
\hline
\end{tabular}

\footnotetext{
${ }^{96}$ Social Security comprises 12.4 percent of the 15.3 percent self-employment tax contribution, or 81.05 percent of self-employment tax.
} 


\section{On-Demand Workers}

Even though independent contractors are often considered to be major contributors to the tax gap because they often deal in cash, many on-demand workers-particularly those doing onplatform work — deal extensively in electronic payment. ${ }^{97}$ How on-demand workers are paidelectronically or by cash or check - and whether they are on-Platform or off-platform workers dictate whether (and if) a worker will receive either a Form 1099-MISC or Form 1099-K. ${ }^{98}$ As noted earlier, research and anecdotal evidence finds that most on-demand platforms have adopted the 200/\$20K Form 1099-K Filing Threshold for reporting income of on-platform workers to the IRS. ${ }^{99}$

As a result, many of the largest on-demand platforms (e.g., Uber, Etsy, Airbnb) do not (and are not required to) provide their on-platform workers with any Form 1099-K because earnings for on-demand platform work, on average, are below the $\$ 20 \mathrm{~K}$ annual threshold or onplatform workers fail to meet the aggregate 200 transaction test. ${ }^{100}$ Academic research has estimated (conservatively) that, for Airbnb alone, "there is approximately $\$ 20$ billion of revenue paid to hosts, the bulk of whom likely do not receive a Form 1099-K." 101

In fact, one survey of on-platform workers that found that in 2015, only 32 percent of ondemand workers received a Form 1099-K or Form 1099-MISC from their on-demand

\footnotetext{
${ }^{97}$ See Part I(C) supra.

${ }^{98}$ Bruckner, supra n. 1.

${ }^{99}$ Senate July 2018 Testimony, supra n. 9.

${ }^{100}$ Id. See also, Uber.com, Understanding Your Tax Documents, (2018) https://www.uber.com/drive/taxinformation/tax-documents (notifying partners that they will only receive 1099-Ks when then meet the $200 / \$ 20 \mathrm{~K}$ Form 1099-K Threshold) (last visited Sept. 23, 2018); Etsy.com, Making Sense of Your Tax Form, (Feb. 21, 2018), https://www.etsy.com/seller-handbook/article/making-sense-of-your-tax-forms/22660467494 (notifying sellers that they will only receive 1099-Ks when then meet the 200/\$20K Form 1099-K Threshold) (last visited Sept. 23, 2018); Airbnb.com, Should I Expect to Receive a Tax Form From Airbnb, https://www.airbnb.com/help/article/414/shouldi-expect-to-receive-a-tax-form-from-airbnb (notifying hosts that they will only receive 1099-Ks when then meet the 200/\$20K Form 1099-K Threshold) (last visited Sept. 23, 2018). See also, JPMCI 2018 Study, supra n. 3 at 14 (detailing the average monthly earnings for the 4 major sectors of the on-demand platform economy, which range from a low of $\$ 608$ (e.g., selling on Etsy) to a high of $\$ 1,736$ (e.g., renting a home on Airbnb). Even if an onplatform worker were to work every month in a year, which is not reflective of what the most research indicates onplatform workers do, average income from that on-platform work still only ranges from $\$ 7,296$ to just over $\$ 20,832$. But even in those cases where leasing a room or renting house would result in $\$ 20,832$, the requirement of more than 200 transactions has to be satisfied. In addition, Airbnb's own research has found "the average American Airbnb host over the age of 65 earns \$8,350 in supplemental income annually for a single listing.” Airbnb, Home Sharing: A Powerful Option to Help Older Americans Stay in their Homes, (Nov. 21, 2016), https://www.aarp.org/content/dam/aarp/livable-communities/documents-2016/Airbnb-HomeSharingOlderAmericans-Report-11-2016.pdf

101 Viswanathan, supra n. 85 at 33.
} 
platform. ${ }^{102}$ More recently, the California Tax Analysis found that in 2016, only 12 percent of the top 100 on-demand platforms issued Form $1099-\mathrm{K}$ to service providers. ${ }^{103}$ This, in turn, leads to significantly higher rates of misreporting by taxpayers according to the latest tax gap research. At best, on-demand workers are underreporting their income when filing their taxes; and at worst, they fail to file all together. ${ }^{104}$

While the research on on-platform work shows that these workers are less likely to get any Form 1099 and more likely to misreport their income, taxpayer industry survey data from 2018 indicates that, generally, self-employed workers either under-report (32 percent) or fail to report (36 percent) their income altogether. ${ }^{105}$ Moreover, when there is underreporting of income on U.S household surveys by self-employed respondents, they underreport by about 30 percent. ${ }^{106}$ These findings are instructive in building a model to estimate for the under- and nonpayment of SE tax by the population of on-demand workers we identified using SIPP.

Specifically, we began with the $\$ 35.97$ billion of earnings of the On-Demand Worker population we estimated using SIPP data. ${ }^{107}$ Using the taxpayer industry survey data findings discussed in Part 1 that only 32 percent of self-employed workers properly report their income while 32 percent underreport and 36 percent failed to report any income altogether, we assumed that 32 percent of these earnings were properly reported for SE tax purposes. This left an approximate gap of $\$ 24.46$ billion potentially underreported or not reported by on-demand workers in 2014. We then segregated the \$24.46 into \$11.51 billion of underreported earnings and $\$ 12.95$ billion of earnings not reported altogether.

From there, we assumed that, consistent with research on underreporting rates by selfemployed workers on household surveys, that on-demand workers underreported their earnings

\footnotetext{
${ }^{102}$ Bruckner, supra n. 1 at 10. The specific survey question asked respondents whether they had received a Form 1099-MISC or Form 1099-K from the on-demand platform they worked with in 2015. Approximately 32 percent of respondents reported receiving a Form 1099; 61 percent reported not receiving a Form 1099 and 6 percent did not know whether they received a Form 1099.

${ }^{103}$ California Tax Analysis, supra n. 52.

${ }^{104}$ House May 2016 Testimony, supra $\mathrm{n} 8$.

105 See supra $\mathrm{n} .28$ and accompanying text.

${ }^{106}$ Hurst, Li \&Pugsley, supra n. 27.

${ }^{107}$ As noted earlier, some of the workers we included in the population of on-demand workers are off-platform workers, and others may have been employees subject to withholding. This reflects some of the limitations of using SIPP data to estimate SE tax of on-platform workers. To provide context for our SIPP data estimates, we developed alternative estimates using the 2017 BLS ACW Survey data on independent contractors, as well as the 2017 ACW Gig Economy Supplement and the JPMCI 2018 Data to contextualize our estimates. See Table 3.
} 
by 30 percent, we calculated that this underreporting would result in an underreporting of $\$ 528$ million of SE tax and \$428 million of Social Security contributions. ${ }^{108}$ To calculate the amount on-demand workers failed to contribute altogether, we multiplied $\$ 12.95$ billion by the SE tax rate (15.3 percent) and determined $\$ 1.98$ billion of SE tax and $\$ 1.61$ billion of Social Security contributions went unpaid. ${ }^{109}$ Collectively, we estimated that on-demand workers failed to contribute \$2.51 billion in SE tax and \$2.03 billion in Social Security in 2014.

Table 2: Estimate of Under- and Nonpayment of Social Security Contributions for OnDemand Workers Using 2014 SIPP Data

\begin{tabular}{|l|l|}
\hline Estimated income from On-Demand Workers (ODW) & \$35.97 Billion ODW Earnings \\
\hline $\begin{array}{l}\text { Estimate of the Amount of ODW Earnings Underreported } \\
(32 \%) \text { and Not Reported (36\%) }\end{array}$ & $\begin{array}{l}\text { \$11.51 Billion (32\% Underreported) } \\
\text { \$12.95 Billion (36\% Not Reported) }\end{array}$ \\
\hline Rate of Underreporting of Earnings & \$3.45 Billion (\$11.51Billion x 30\%) \\
\hline Estimated amount of SE Tax Not Paid by ODW & $\$ 2.51$ Billion \\
\hline Estimated amount of Social Security contributions Not Paid & \$2.03 Billion \\
\hline
\end{tabular}

\section{Alternative Estimates}

To provide context for our SIPP data estimates, we also estimated how much SE tax went underreported by the 10.6 million independent contractors identified in the 2017 BLS ACW Survey. In addition, we estimated how much SE tax went underreported by the 2.3 million onplatform workers identified in the 2017 ACW Gig Economy Supplement as well as the JPMCI 2018 Study. To calculate the independent contractor underreporting of SE tax estimate from the 2017 BLS ACW Survey, we used 44.2 percent underreporting rate of SE tax we derived from the 2007 TIGTA Audit. For the on-platform workers counted in the 2017 ACW Gig Economy Supplement and JPMCI 2018 Study, we assumed 68 percent of the workers counted in these estimates did not receive any Form 1099 and then applied a 63 percent likelihood of underreporting to our results. ${ }^{110}$ We then used the average underreporting amount of $\$ 1,542$ we derived from the 2007 TIGTA Audit to estimate a collective amount.

\footnotetext{
${ }^{108}$ Hurst, Li \&Pugsley, supra n. 27.

109 See supra note 96 and accompanying text.

${ }^{110}$ We believe 68 percent to be a reasonable assumption because it is consistent with prior survey data specifically asking respondents working with on-demand platforms whether they received any Form 1099 for their on-platform work. An alternative is to rely on the data from the California Tax Analysis that found that only 12 percent of the Top 100 Platforms in 2016 issued 1099-Ks, however, the California Tax Analysis does not consider whether Form 1099-MISCs were issued instead of Form 1099-K. See supra n. 52 and accompanying text.
} 
Similar to using SIPP data to derive estimates of SE tax underpayment for independent contractors and on-demand workers, there are limitations with using these alternative data sets and the estimates we derived are not without qualification. For example, the number of onplatform workers included in the JPMCI 2018 Study includes workers who earned income from rental activities not likely subject to SE tax. In addition, we did not have the collective earnings of these populations, so we used an alternative methodology to illustrate underreporting. This alternative methodology did not consider how much these workers failed to contribute SE tax altogether. Had we included non-reported amounts, the estimates would likely be significantly higher - we erred on the side of caution and assumed that the workers who misreported their income merely underreported their SE Tax by $\$ 1,542$ rather than failed to contribute altogether. These results are set forth in Table 3.

Table 3: Comparison of Estimates of Underpayment of SE Tax and Social Security Contributions BLS 2017 ACW Survey Data

\begin{tabular}{|l|l|l|l|}
\hline $\begin{array}{l}\text { Summary of 2014 } \\
\text { SIPP and BLS } \\
\text { 2017 ACW Data }\end{array}$ & $\begin{array}{l}\text { Independent } \\
\text { Contractors } \\
\text { BLS 2017 ACW } \\
\text { Survey }\end{array}$ & $\begin{array}{l}\text { On-Platform Workers } \\
\text { 2017 ACW Gig } \\
\text { Economy Supplement }\end{array}$ & $\begin{array}{l}\text { JPMCI 2018 Study } \\
\text { of On-Platform } \\
\text { Workers }\end{array}$ \\
\hline $\begin{array}{l}\text { Total \# of } \\
\text { Workers }\end{array}$ & $10,600,000$ & $1,600,000$ & $2,300,000$ \\
\hline $\begin{array}{l}\text { Total \# of } \\
\text { Workers } \\
\text { Underreporting } \\
\text { SE Tax Liabilities }\end{array}$ & $\begin{array}{l}4,685,200 \\
(10.6 \mathrm{M} \times 44.2 \%)\end{array}$ & $\begin{array}{l}685,400 \\
(1.6 \mathrm{M} \times 68 \% \times 63 \%)\end{array}$ & $\begin{array}{l}1,564,000 \\
(2.3 \mathrm{M} \times 68 \% \times 63 \%)\end{array}$ \\
\hline $\begin{array}{l}\text { Total Amount of } \\
\text { SE Tax } \\
\text { Underreported } \\
\text { \$1,542) }\end{array}$ & $\$ 7.22$ Billion & $\$ 1.05$ Billion & $\$ 1.5$ Billion \\
\hline $\begin{array}{l}\text { Total Amount of } \\
\text { Underreported } \\
\text { Social Security } \\
\text { Contribution }\end{array}$ & $\$ 5.85$ Billion & $\$ 856$ Million & $\$ 1.2$ Billion \\
\hline
\end{tabular}




\section{Demographics of the SIPP Data Independent Contractor and On-Demand Workforce, and the Effects of Underpayment on Social Security Benefits}

As noted earlier, this paper seeks not only to quantify the impact of independent contractors and on-demand workers' likely underpayment of SE tax and Social Security contributions, but also to consider the implications of those underpayments in terms of what it means for these workers' Social Security benefits. Important groundwork on these issues has already been done and some research has already considered the economic security of U.S. ondemand workers and what this kind of work means for these workers' retirement. ${ }^{111}$

For example, a 2015 International Labour Office survey of Amazon Mechanical Turk and Crowdflower workers in the United States and India found that most of the U.S. workers who use platform work as their main source of income "lack Social Security coverage ... a mere 8.1 percent of main job crowd workers in the U.S. report making regular contributions to a private retirement account and only 9.4 percent contribute to Social Security, raising concerns about the financial situation of these workers when they reach retirement age."112 Moreover, other critical research on the retirement issues facing on-demand workers has reiterated the reality that because most on-demand platforms classify their workers as independent contractors, those workers, "are approximately two-thirds less likely than standard employees to have access to employer-provided retirement plans."113

SIPP provides a unique opportunity to consider the impact of the failure to contribute to Social Security and other retirement security issues of independent contractors and on-demand workers beyond their earnings because of the demographic information it collects. Unlike our previous discussions of the size and earnings of independent contractors and on-demand economy workers, there appears to be more consensus between governmental reports and private-sector reports on the demographics of the independent contractors and on-demand economy workforce.

\footnotetext{
${ }^{111}$ Berg, surpa n. 13 at 16.

${ }^{112} I d$. Crowdwork is a kind of work performed remotely on on-line platform where workers perform "micro-tasks" and are paid for singular tasks in response to business' posts via platforms. Typical categories of tasks include: researching information on the internet; verifying tweets; completing academic surveys; and content access. Id. ${ }^{113}$ Secunda, supra n. 13 at 3. Importantly, Secunda's article is the first argue that on-demand workers be treated as common-law employees for retirement purposes to qualify for ERISA purposes.
} 
For example, in a 2015 report, GAO found that independent contract workers-including on-demand workers - more often appear to be younger, rather than older; men, rather than women; and more often Hispanic, rather than any other race or ethnicity. ${ }^{114}$ Similarly, MBO Partners in its 2018 report describes the average independent contractor as a Millennial who is aged 21 to 38 and is slightly more likely to be male than female. ${ }^{115}$ Most recently, the JPMCI 2018 Study confirmed a number of these findings - particularly with respect to those on-platform workers earning income in the transportation sector, which is by far the largest sector of the ondemand economy. ${ }^{116}$ However, interestingly, that same study found that there were more women than men in each of the other sectors (i.e., non-transport work, selling and leasing), but relative transportation, those other sectors were a small portion of the on-demand economy. ${ }^{117}$

\section{SIPP Demographic Data on Independent Contractors and On-Demand Workers}

Using SIPP, as displayed in Figure 1 we estimated that Baby Boomers or individuals aged 55 and over (50.68 percent) in 2014 were more often independent contractors, followed by Generation X or individuals aged 34 to 54 (26.06 percent) in 2014 and Millennials aged 18 to 33 (23.36 percent) in 2014. We found that Independent contractors were more likely to be women (55.88 percent) than men (44.12 percent), as displayed in Figure 2. And we found that independent contractors were more often White (67.47 percent), than Hispanic/Latino (14.57 percent), Black (12.39 percent), or Asian (5.65 percent) individuals as shown in Figure 3.

\footnotetext{
${ }^{114}$ GAO-15-168R, supra $\mathrm{n} .62$ at 5 .

${ }^{115}$ MBO 2018 Report, supra n. 4 at 8.

${ }^{116}$ JPMCI supra $\mathrm{n} .2$ at 22.

${ }^{117} \mathrm{Id}$. Going forward, it will be interesting to see what happens with the transportation sector of the On-Demand Economy with the advent of driverless cars. See Gene Munster, "Here's When Having a Self-Driving Car Will be a Normal Thing," Fortune (Sept. 13, 2017), http://fortune.com/2017/09/13/gm-cruise-self-driving-driverlessautonomous-cars (predicting self-driving cars won’t have an impact in a "noticeable way until 2020.").
} 


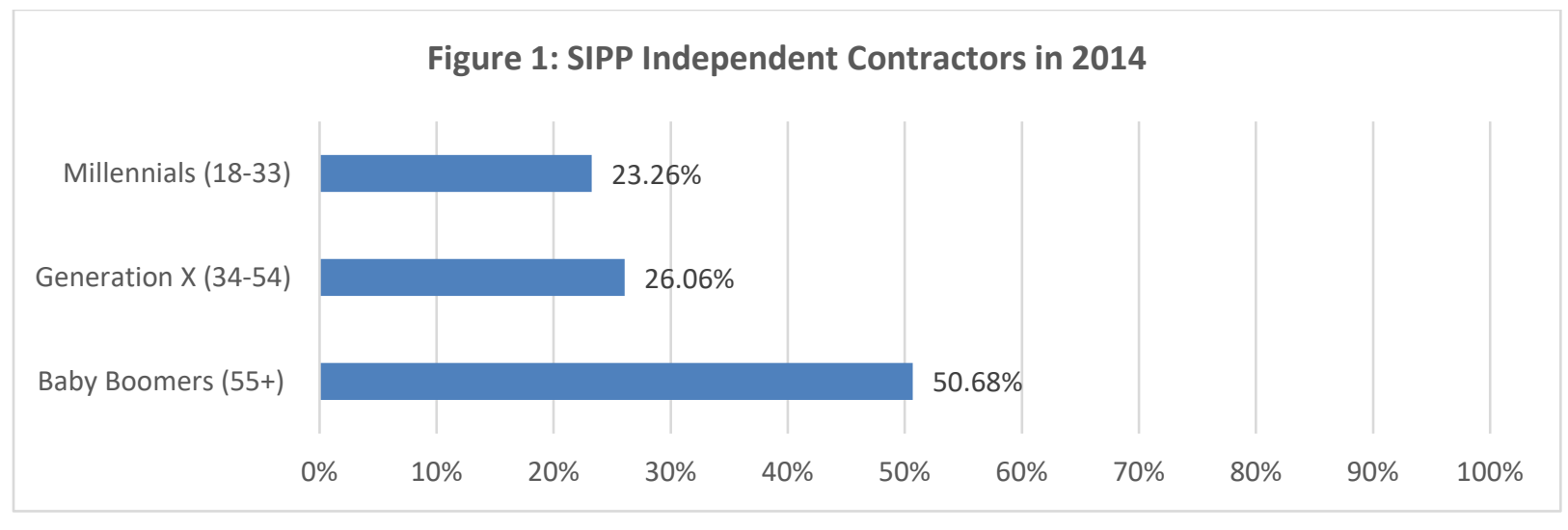

Figure 2: SIPP Independent Contractors By Gender, in 2014

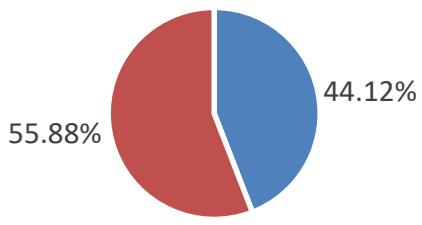

- Men - Women

Figure 3: SIPP Independent Contractors By Race/Ethncity 2014

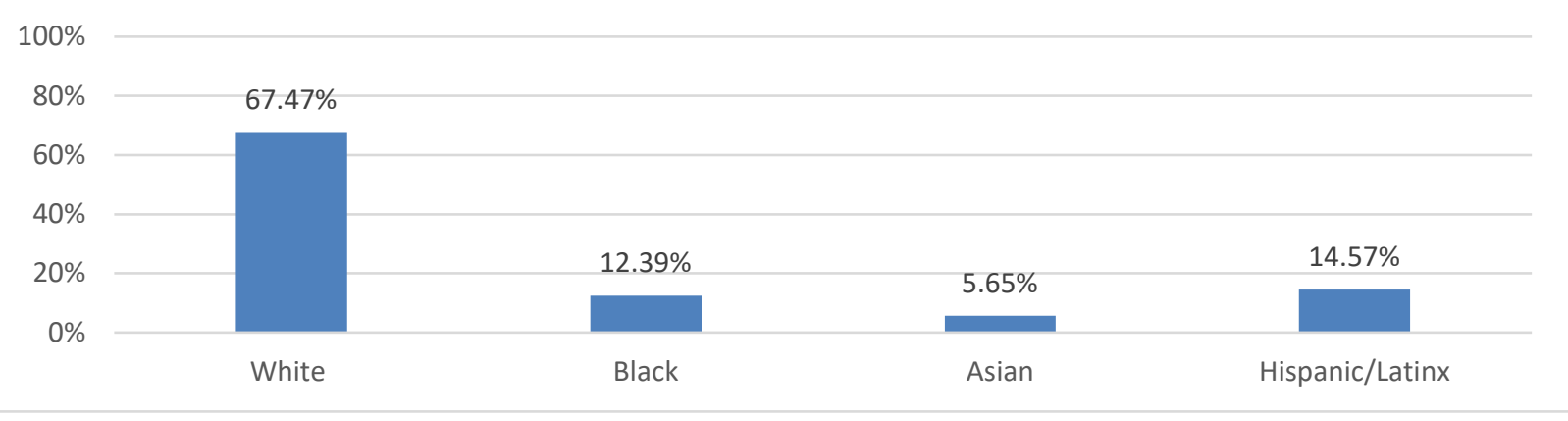

With respect to the population of on-demand workers we identified using SIPP, as displayed in Figure 4, we found that Generation X (45.40 percent) were more often engaged as on-demand workers than Baby Boomers (36.82 percent) and Millennials (17.78 percent). Additionally, we found that on-demand workers were slightly more likely to be women (51.81 percent) than men (48.18 percent) (Figure 5). Finally, we found that on-demand workers were most often White (67.03 percent), than Hispanic/Latino (20.45 percent), Black (9.74 percent), or Asian (2.73 percent) as shown in Figure 6. 

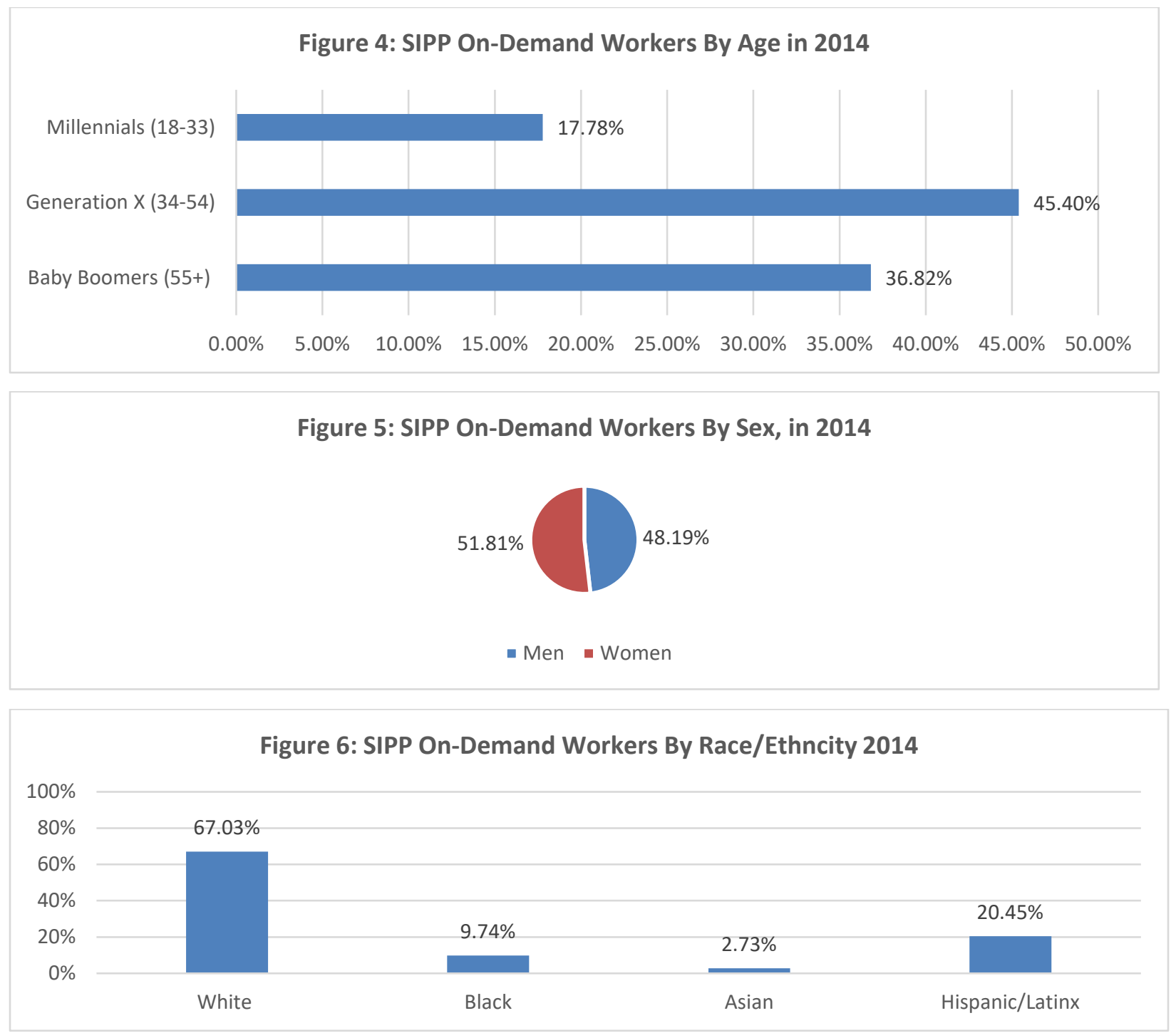

These results are somewhat consistent with readily available data from at least one OnDemand Platform: Airbnb. In a March 2016 report detailing Airbnb's growing population of women hosts over 60 years old, Airbnb researchers found that seniors are the fastest growing demographic (and best rated) of Airbnb hosts in the United States; and that the majority of women hosting on Airbnb are "empty nesters looking to make ends meet."118 More recently, in March 2018, Airbnb touted its success with helping DC senior hosts to age in their homes. ${ }^{119}$ Our SIPP results indicates that on-demand workers are older than most other estimates suggest,

\footnotetext{
${ }^{118}$ See Airbnb, supra n. 7. However, most rental income is not subject to SE tax, and would not be included in calculating Social Security benefits.

${ }^{119}$ See Airbnb, supra n. 7
} 
and are slightly more likely women. Apart from rental income, which is generally not subject to SE tax, earnings of on-demand workers could have a large impact on their Social Security benefit receipt.

\section{Implications for Social Security Benefits}

Social Security benefits are based on a worker's earning history and age at retirement, and are designed to "replace part of a worker's earnings." 120 A worker is eligible for Social Security after he or she works in a Social Security-covered employment for 10 or more years (i.e., 40 earnings credits or 4 credits/year). ${ }^{121}$

In 2018, self-employed individuals earn one credit for every $\$ 1,320$ of earnings and a worker who earns more than $\$ 5,280$ receives four work credits, or the maximum that can be earned in one year. ${ }^{122}$ Additionally, a worker's initial monthly benefit is based on their 35 highest years of earnings, which are indexed to historical wage growth. The 35 highest years of indexed earnings are divided by 35 to determine the worker's career-average annual earnings. The resulting amount is divided by 12 to determine the worker's Average Indexed Monthly Earnings (AIME). Workers with fewer than 35 years of earnings in covered employment or years of no earnings, have zeroes entered in the computation, resulting in a lower AIME and therefore a lower monthly benefit. ${ }^{123}$

The Social Security benefit is progressive in that it provides workers with low lifetime earnings with a benefit that represents a higher percentage of their pre-retirement income than higher-income workers. ${ }^{124}$ However, benefits are proportional to average lifetime earnings, and for workers with lower lifetime earnings — such as women — benefits calculated under the regular formula will be low. ${ }^{125}$ This exacerbates existing challenges for women: in 2015, the average benefit for women was $\$ 14,184$, compared to $\$ 18,000$ for men. ${ }^{126}$ Often, women take time out of

\footnotetext{
${ }^{120}$ CRS Report R42035, supra n. 11 at 7.

${ }^{121} \mathrm{Id}$.

122 Social Security Administration, If You Are Self-Employed (2018), https://www.ssa.gov/pubs/EN-05-10022.pdf.

${ }^{123}$ CRS Report R42035, supra n. 11 at 8.

124 Joan Entmacher \& Amy Matsui, Addressing the Challenges Women Face in Retirement: Improving Social Security, Pensions, and SSI, 46 J. Marshall L. Rev. 749 (2013), https://repository.jmls.edu/cgi/viewcontent.cgi?article=1216\&context=lawreview.

${ }^{125} \mathrm{Id}$.

${ }^{126}$ Stan-Hidden, Women and Social Security Benefits, AARP, (Feb. 2017), https://www.aarp.org/work/socialsecurity/info-2014/women-and-social-security-benefits.html.
} 
the work force to care for family, and as a result, do not earn credits towards their Social Security benefits during that time and have a lower AIME. ${ }^{127}$

At the same time, academic research has resoundingly concluded that women are "more vulnerable" than men in retirement because women reach retirement with less retirement savings, assets and Social Security benefits than men, but women tend to live longer and have more health care costs. ${ }^{128}$ In addition, "for all but the highest income families, Social Security provides the largest source of retirement income." 129 For women in particular, Social Security income, as modest as it may be for women on average, is the only income keeping nearly half of women 65 and older from poverty. ${ }^{130}$

\section{Implications for Social Security Solvency}

Given the critical role Social Security plays in keeping so many beneficiaries out of poverty, our estimate of the $\$ 5.95$ billion in Social Security contributions that were likely not contributed as a result of the approximate underpayment of $\$ 7.35$ billion in self-employment taxes in 2014 by independent contractors and on-demand workers merits additional analysis in terms of its implications for the solvency of Social Security.

Social Security faces long-term financing difficulties. In its most recent report (the "2018 Trustees' Report"), the Social Security Trustees project that for 2018, the cost of the program will exceed total income by $\$ 2$ billion and non-interest income by $\$ 85$ billion. ${ }^{131}$ Additionally, the 2018 Trustees' Report estimates that the trust funds currently have $\$ 2,892$ billion in reserves and estimates that the funds will be able to pay full benefits until 2034 - one year earlier than the 2017 Trustees' Report projection. ${ }^{132}$ After 2034, payroll and self-employment taxes will cover about 75 percent promised benefits. ${ }^{133}$

\footnotetext{
${ }^{127} \mathrm{Id}$.

${ }^{128}$ Etmacher \& Matsui, supra n. 120 at 749.

${ }^{129} I d$.

${ }^{130}$ Id. at 751.

${ }^{131}$ The Board of Trustees, Federal Old-Age and Survivors Insurance and Federal Disability Insurance Trust Funds, "The 2018 Annual Report of the Board of Trustees of the Federal Old-Age and Survivors Insurance and Federal Disability Insurance Trust Funds," (June 5, 2018) https://www.ssa.gov/oact/TRSUM (last visited Sep 8, 2018). ${ }^{132} I d$.

${ }^{133} I d$.
} 
Using SIPP we estimated that approximately $\$ 3.92$ billion in underpayment of Social Security contributions from independent contractors and $\$ 2.03$ billion in under-and nonpayment from on-demand workers in 2014. Historically, government research on sole proprietors has found high rates of underreporting for their income - even higher than we used in calculating our estimates. ${ }^{134}$ And while that research may precede the advent of the on-demand economy, the data we used from SIPP might, too. The on-demand economy has grown substantially since 2014 and added millions of workers in the last four years, who may not have been captured by our SIPP data. In addition, our estimates for underpayment of SE tax of independent contractors are based on averages of underpayment of SE tax and do not account for the likely non-payment of tax by this population altogether.

As a result, we suspect that our estimates, if anything, are conservative as to the regular underpayment of SE tax by the independent contractors and on-demand workers we estimated, particularly with respect to those on-platform workers we included, the majority of whom will not receive any Form 1099 to prompt proper reporting of their income. ${ }^{135}$ Moreover, with respect to the off-platform workers we included in our on-demand workers estimates, we think that innovations in terms of digitizing payments suggests that more off-platform workers are (and will be) paid in ways not subject to information reporting under current law. ${ }^{136}$

Even the most robust research on the size, scope and earnings of on-demand economy workers concedes that new payment options could involve bypassing a bank account entirely, which could result in undercounting of the participants in the on-demand platform economy. ${ }^{137}$ Even with the forgoing qualifications, we find that there is at the very least an annual $\$ 7.35$ billion in underpayment of SE tax by these workers that could be addressed with the intent of shoring up the overall solvency of Social Security and to ensure that workers' AIME is properly calculated.

\footnotetext{
${ }^{134}$ See e.g., White, surpa n. 95.

135 See Part I(C).

${ }^{136}$ Ryan Brown, Digital Payments Expected to Hit 726 Billion by 2020-But Cash Isn't Going Anywhere Yet, CNBC, (Oct. 9, 2017), https://www.cnbc.com/2017/10/09/digital-payments-expected-to-hit-726-billion-by-2020study-finds.html (quoting private sector report finding non-cash transactions between 2014 and 2015 rose 11.2 percent, the highest growth of the past decade).

${ }^{137}$ JPMCI 2018 Study, supra n. 3 at 9.
} 


\section{Policy Proposals to Address Tax Compliance Challenges}

As part of its recommendations for shoring up the long-term financing of Social Security, the 2018 Trustees' Report recommends Congress act sooner rather than later "so that a broader range of solutions can be considered and more time will be available to phase in changes while giving the public adequate time to prepare. Earlier action will also help elected officials minimize adverse impacts on vulnerable populations, including lower-income workers and people already dependent on program benefits." 138 To facilitate tax administration, compliance and aid independent contractors generally, and On-Platform service providers and sellers specifically, Congress may consider taking action. Potential policy options to address these challenges include: updating and aligning information reporting requirements, updating quarterly-estimated filing due dates, and requiring that the IRS develop tax guidance for ondemand platforms that can be provided to service providers and sellers as part of the on-boarding process. A discussion of these options follows.

\section{Updating and Aligning the Form 1099-MISC and 1099-K Reporting Thresholds}

Academic research has concluded that, under certain circumstances, enhanced information reporting can reduce the tax gap. ${ }^{139}$ In fact, "the degree to which taxpayers fail to include income on their tax returns, or underreport, is directly related to the extent these income items are subject to information reporting." 140 Given the current practice adopted by the majority of on-demand platforms to use the 200/\$20K Form 1099-K Reporting Threshold for furnishing Form 1099-Ks to on-platform workers, Congress could consider moving forward with modernizing the information reporting regime by significantly lowering the dollar amount for the filing threshold for Form 1099-K and limiting the aggregate 200 transaction threshold. At the same time, Congress could consider updating the Form 1099-MISC threshold by raising it from $\$ 600$ to align with a new, lower Form 1099-K threshold and provide some relief for small businesses who are subject to the Form 1099-

\footnotetext{
1382018 Trustees' Report, supra n. 127.

${ }^{139}$ Leandra Lederman, Reducing Information Gaps to Reduce the Tax Gap: When is Information Reporting Warranted?. Fordham Law Review Vol. 78, p. 1733, 2010; Indiana Legal Studies Research Paper No. 126. Available at SSRN: https://ssrn.com/abstract=1347668 (noting increased information reporting is not a "panacea" and that increased reporting imposes costs). See also, Viswanathan, supra n. 85 (explaining how absent legislative intervention, on-demand platforms "pose a critical threat to the reporting system underlying domestic and international tax compliance.").

${ }^{140}$ Viswanathan, supra n. 85 at 7.
} 
MISC filing rules for the independent contractors they hire. Note that the Form 1099-MISC filing thresholds have not been fundamentally reviewed or updated since at least 1954. ${ }^{141}$ Adjusted for inflation, $\$ 600$ in 1954 would be more than $\$ 5,000$ in today's dollars. ${ }^{142}$ At least two legislative proposals introduced in the $115^{\text {th }}$ Congress proposed aligning the Form 1099-K and Form 1099-Misc Thresholds. ${ }^{143}$

Congress is generally aware of the budgetary impact this type of proposal would have and how it could translate to increased federal revenues. As part of its 2017 tax reform debate work, the Joint Committee on Taxation (JCT) provided a score for a version of this proposal that would align the Forms 1099-MISC and Form 1099-K at \$1,000 and estimated that it could raise as much as approximately $\$ 3.6$ billion over a 10 -year budget window. ${ }^{144}$

Some states have already moved forward with this approach and aligned the 1099-K and 1099-MISC reporting thresholds at the current 1099-MISC level of $\$ 600$ with positive results. ${ }^{145}$

\section{Updating Quarterly-Estimated Payment Due Dates}

As noted earlier, when self-employed taxpayers are expected to owe at least $\$ 1,000$ in taxes and aren't subject to withholding, advance payments of estimated tax are due to the IRS throughout the year in the form of quarterly-estimated payments. ${ }^{146}$ Research on the tax compliance of ondemand platform workers found that more than one-third of respondents did not know whether they were required to file quarterly estimated payments on the income they earned working with a platform. ${ }^{147}$

\footnotetext{
${ }^{141}$ See P.L. 83-591, which was enacted on Aug. 16, 1954 and which created IRC Section 6041 with the original $\$ 600$ threshold.

${ }^{142}$ H.R. 3717 takes the approach of aligning the Form 1099 threshold filing requirements at \$1,500, among other tax changes targeted to small business. Other bills, notably, S. 1549, would align the thresholds at $\$ 1,000$. S. 1549 goes further and includes other provisions on misclassification and provides for voluntary withholding agreements to be instituted between platforms and their service providers and sellers.

${ }^{143} \mathrm{Id}$.

${ }^{144}$ JCT, Estimated Revenue Effects Of The Chairman's Mark Of The "Tax Cuts And Jobs Act," Scheduled For Markup By The Committee On Finance On November 13, 2017 (JCX-52-17) (Nov. 9. 2017), available at https://www.jct.gov/publications.html?func=startdown\&id=5033.

${ }^{145}$ In 2017 both Vermont and Massachusetts began to require information reporting for income earned by small business on-demand platform operators and paid electronically at the current 1099-MISC threshold of $\$ 600$. According to the industry experts, the lower reporting threshold in Massachusetts "catapulted reporting by over 100 percent." Senate July 2018 Testimony, supra n. 9.

${ }^{146}$ Form 1040 Estimated Tax for Individuals, Internal Revenue Service (July 23, 2018), https://www.irs.gov/formspubs/about-form-1040-es. ${ }^{147}$ House May 2016 Testimony, supra n. 7.

${ }^{147}$ House May 2016 Testimony, supra n. 7.
} 
The IRS National Taxpayer Advocate has repeatedly recommended that anything that can be done "to help taxpayers make their estimated tax payments more easily and lessen the burden of saving to make such payments is likely to increase compliance." ${ }^{148}$ In order to facilitate tax compliance and ease taxpayer burden, Congress may consider updating the filing deadlines for second and third quarter installment payments set forth in IRC Section 6654(c) to be due two weeks after a quarter's end, rather than in the middle of a quarter as is required under current law.

This change is likely to increase compliance because under current law "taxpayers must remember oddly spaced payment dates ... [that] do not consistently coincide with calendar quarters, making difficult to calculate net income and confusing to tax payers." 149

Requiring the IRS to Develop and Publish Guidance for On-Demand Platforms to Provide Service Providers and Sellers as Part of the On-Boarding Process

Survey data of experienced on-platform workers found that there is a significant knowledge gap between what taxpayers understand their tax obligations to be, if any, and what they actually are. ${ }^{150}$ Many on-demand platforms are hesitant to provide tax information to their workforce due to ongoing concerns and litigation over misclassification issues. ${ }^{151}$ To address the knowledge gap, the National Taxpayer Advocate has recommended the IRS develop a checklist for first-time, selfemployed on-demand economy workers and sellers. Anecdotal and survey evidence suggests taxpayers want to do right thing, but are unfamiliar with the requirements of quarterly estimated payments. ${ }^{152}$ By the time taxpayers learn that they have failed to file quarterly estimated payments on this income; many just walk away and fail to file altogether. By developing accessible content that on-demand platforms can distribute to service providers and sellers as part of the onboarding process, the IRS can make immediate progress in addressing the knowledge gap even experienced, self-employed small business owners have.

\footnotetext{
148 The Sharing Economy: A Tax Experience for New Entrepreneurs Part II: Hearing Before the House Comm. on Small Business, $113^{\text {th }}$ Congress (2016)(statement of Nina Olson, IRS National Taxpayer Advocate) available at https://smallbusiness.house.gov/uploadedfiles/national_taxpayer_advocate_testimony-5-26-2016_hearing.pdf. ${ }^{149} \mathrm{Id}$.

${ }^{150}$ Bruckner, supra n. 1.

151 Senate July 2018 Testimony, supra n. 9.

152 See Part 1(B) supra.
} 


\section{Conclusion}

Our intent in this paper is to shed light on the Social Security implications of the current federal tax rules for self-employed, non-employer workers working outside of a traditional employment relationship and for self-employed individuals working in on-demand occupations by estimating the size of and earnings of this population, using the U.S. Census Bureau's redesigned Survey of Income and Program Participation (SIPP). Ultimately, we estimated there were 7.1 million independent contractors and 3.1 million on-demand workers earning selfemployment income in 2014. These workers are likely to have failed to contribute as much as $\$ 7.35$ billion in SE Tax in 2014, which translates to at least $\$ 5.95$ billion in underpaid Social Security contributions.

The research on measuring these workers is dynamic, but there appears to be consensus that on-demand workers are hard to measure in terms of size, composition and earnings. However, even with conservative estimates on the underpayment of SE tax, there remains a significant probability that millions of the workers we estimated are not paying into Social Security. This is a particularly acute problem for women, who tend to have greater dependency on Social Security and lower contributions over the course of their working lives. And this problem will continue to grow along with the digitizing of the cash economy. However, there are limited steps Congress may consider to modernize information reporting, update quarterly estimated payment requirements and require distribution of tax guidance to help address these issues and further support the solvency of Social Security. 


\section{Methodology}

For preparing the estimates included in this paper, we extrapolated data from U.S. Census Bureau's Survey of Income and Program Participation (SIPP) on populations of workers we identified as independent contractors and on-demand workers, including the overall number of workers in these groups and their collective earnings. We then surveyed academic literature and existing National Bureau of Economy Research, U.S. Department of Treasury and IRS reports on: 1) the tax gap; 2) underreporting and underpayment of self-employment taxes; and 3) tax compliance surveys of workers using on-demand platforms for selling goods and services. We also relied on 2018 tax preparer industry survey data on the under-and nonreporting of income by self-employed workers.

To develop an average underpayment amount we could apply to the population of independent contractors and on-demand workers, we analyzed data from the 2007 TIGTA Audit to determine that: 1) 44.2 percent of returns that TIGTA included in its statistically valid sample reported Schedule C or Schedule F income, but did not include a Schedule SE and had an underpayment of SE tax; and 2) the average underpayment of self-employment tax liability was $\$ 1,542$.

To calculate the number and amount of independent contractors underreporting selfemployment tax liability, used the following assumptions: that 44.2 percent of the 7.1 million independent contractors we identified using SIPP underreported their SE tax liability on their 2014 Form 1040s - on average - by $\$ 1,542$. We also assumed the collective earnings of this population of $\$ 204.1$ billion translated to $\$ 28,746.48$ of earnings on average, and that the average underpayment of SE tax on these earnings was 35.1 percent. We calculated this would result in $\$ 4.84$ billion in additional SE tax that should have been collected on this income in 2014 and that approximately $\$ 3.92$ billion of this amount is underreported Social Security contributions. To compare our results with more recent data sets, we ran a variation of these calculations using the 10.6 million independent contractor population from the 2017 BLS ACW Survey. This calculation assumed that 44.2 percent of that population underreported their earnings by $\$ 1,542$.

With respect to our estimates for on-demand workers, because our population data was likely over inclusive and our earnings data was under representative, we calculated our estimates using the total SIPP earnings data of on-demand workers, and then assumed that: 1) 32 percent 
of those earnings were properly reported; 2) 32 percent of those earnings were underreported by 30 percent; and 3) 36 percent of the collective earnings went unreported altogether.

With respect to the 2.3 million on-platform workers identified in the JPMCI 2018 Study and the 1.6 million on-platform workers identified in the 2017 ACW Gig Economy Supplement, we assumed that: 1) 68 percent of on-demand workers did not receive a Form 1099-K or Form 1099-MISC for their self-employment income; and 2) 63 percent of the population of on-demand workers that did not receive any Form1099 misreported their income. We then multiplied the average SE tax underpayment of $\$ 1,542$ to those populations to calculate the total underreported SE tax and Social Security Contribution.

\section{Research Question(s):}

1) Using SIPP, how many individuals are freelance, independent contractors, and selfemployed individuals ("independent contractors")"

2) Using SIPP, how many workers are using on-demand, app-based platforms or working in occupations occurring in the on-demand economy ("on-demand workers")?

3) Using SIPP, how much income was earned by independent contractors and on-demand workers?

4) How much SE tax should have been collected on this income?

5) What was the Social Security underpayment amount from this income?

6) What are the Social Security implications for these workers and the solvency for Social Security?

\section{About the Survey of Income and Program Participation (SIPP)}

To prepare the estimates in this paper, we used the U.S. Census Bureau's Survey of Income and Program Participation (SIPP). SIPP is a longitudinal, multi-panel survey of adults in the United States. Each panel features a nationally representative sample interviewed over a multi-year period lasting approximately two and a half to four years. The size of the sample ranges from 14,000 to 52,000 households. In comparison to other nationally representative surveys, SIPP fills the gaps that other surveys such as the Current Population Survey (CPS) leave, by providing data that affords a better understanding and analyses of the distribution of income, wealth, and poverty in the United States and of the effects of federal and state programs on the well-being of 
families and individuals.

The core questions cover demographic characteristics, labor force participation, program participation, amounts and types of earned and unearned income received, including transfer payments and noncash benefits from various programs, and asset ownership. Additionally, SIPP is larger than comparable surveys such as the Survey of Consumer Finances (SCF) and provides information on business ownership that is not found in surveys such as the SCF.

With respect to labor and earnings questions, SIPP collects information about an individual's work history from the beginning of the reference year through the interview month. Specifically,

"Topics covered include the weeks of employment, amount and type(s) of earnings, and business characteristics. For respondents with a period time not working, SIPP collects data on the reasons why the respondent did not hold a job, and whether the respondent looked for work. Basic information about the job such as beginning and ending dates, the type of work arrangement, and reason for the job ending (when applicable) are collected first. The next questions are characteristics of the job/business such as industry, occupation, union status, the number of employees, and incorporation status. Next the survey asks about the types of earnings the respondent received (wage/salary, commission, tips, overtime or bonus), the amounts earned, and the number of hours worked per week. Finally, the survey asks respondents to report any time they were away from the job without pay within the reported job spell. For those periods when the respondent was not employed, information is collected about the labor force status of the respondent during that period. This includes information about why they were not working, unpaid work in a family business or farm, time spent on layoff and time spent looking for work. The 2014 Panel allows respondents to report detailed information for up to seven jobs and up to three periods of time away without pay. Respondents may report up to two changes in wage/salary pay rate and hours worked for each job over the reference period." 153

\footnotetext{
${ }^{153}$ SIPP Content U.S. Census Bureau, https://www.census.gov/programs-surveys/sipp/about/sipp-content-
} information.html\#par_abstract_7, (last visited Sep 8, 2018). 


\section{Variables Used}

EJB1_JBORSE through EJB7_JBORSE:

Description: This variable describes the type of work arrangement, whether work for an employer, self employed or other.

- Universe Description: Respondents who held a job during the reference month. TJB1_EMPALL through TJB7_EMPALL:

Description: About how many people are employed by ... at ALL LOCATIONS together?

- Universe Description: Respondents who had a job or a definite work arrangement and their employer operated in more than one location during the reference period.

\section{TJB1_EMPB through TJB7_EMPB:}

Description: What is the maximum number of employees, including ..., working for ... at any given time?

- Universe Description: Respondents who were self-employed during the reference period. TJB1_OCC through TJB7_OCC:

Description: Occupation code Universe

- Description: Respondents who worked for an employer, were self-employed or had another work arrangement

Despite its advantages, SIPP has its limitations. As with most survey data, SIPP data is selfreported, which can be problematic for the reporting of self-employment, income received from a particular source, and the payment of taxes. In addition, the SIPP survey data on selfemployment does not specifically identify individuals who earn income working with ondemand platforms. Instead, we have identified individuals with occupations occurring in the ondemand economy as reflected by their SIPP survey responses. To provide additional context for the SIPP data we have included, we also included the most recent data collected in connection with the 2017 BLS ACW Survey as well as the JPMCI 2018 Study. 


\section{RECENT WORKING PAPERS FROM THE CENTER FOR RETIREMENT RESEARCH AT BOSTON COLLEGE}

How Much Income Do Retirees Actually Have? Evaluating the Evidence from Five National Datasets

Anqi Chen, Alicia H. Munnell, and Geoffrey T. Sanzenbacher, November 2018

The Minimum Wage and Incentives for Full-Time Work Under the Social Security Retirement Earnings Test

Gary V. Engelhardt, October 2018

Would Greater Awareness of Social Security Survivor Benefits Affect Claiming Decisions? Anek Belbase and Laura D. Quinby, October 2018

How Does Delayed Retirement Affect Mortality and Health?

Alice Zulkarnain and Matthew S. Rutledge, October 2018

How Have Automation and Trade Affected the Taxable Share of Covered Earnings? Gal Wettstein, Matthew S. Rutledge, and Wenliang Hou, October 2018

Spillovers from State and Local Pensions to Social Security: Do Benefits for Uncovered Workers Meet Federal Standards?

Laura D. Quinby, Jean-Pierre Aubry, and Alicia H. Munnell, September 2018

Accounting for Social Security Claiming Behavior

Svetlana Pashchenko and Ponpoje Porapakkarm, September 2018

The Minimum Wage and Annual Earnings Inequality

Gary V. Engelhardt and Patrick J. Purcell, August 2018

Exploring the Consequences of Discrimination and Health for Retirement by Race and Ethnicity: Results from the Health and Retirement Study

Ernest Gonzales, Yeonjung Jane Lee, William V. Padula, and Lindsey Subin Jung, July 2018

Financial Management Support for SSA Beneficiaries: Looking Beyond the Payee Annie Harper, May 2018

What Factors Explain the Decline in Widows' Poverty?

Alicia H. Munnell, Geoffrey T. Sanzenbacher, and Alice Zulkarnain, May 2018

Exploring the Rise of Mortgage Borrowing among Older Americans

J. Michael Collins, Erik Hembre, and Carly Urban, May 2018

All working papers are available on the Center for Retirement Research website

(http://crr.bc.edu) and can be requested by e-mail (crr@bc.edu) or phone (617-552-1762). 